\title{
Ice-rafted debris as a source of non-conservative behaviour for the $\varepsilon N d$ palaeotracer: insights from a simple model
}

\author{
Noam Vogt-Vincent ${ }^{1,2}$ (D) Jörg Lippold ${ }^{2}$ (D) $\cdot$ Stefanie Kaboth-Bahr ${ }^{2,3}$ (D) Patrick Blaser $^{2}$ (D)
}

Received: 20 August 2019 / Accepted: 21 February 2020 / Published online: 18 March 2020

(C) The Author(s) 2020

\begin{abstract}
Neodymium isotopic composition $(\varepsilon \mathrm{Nd})$ has enjoyed widespread use as a palaeotracer, principally because it behaves quasiconservatively in the modern ocean. However, recent bottom water $\varepsilon \mathrm{Nd}$ reconstructions from the eastern North Atlantic are difficult to interpret under assumptions of conservative behaviour. The observation that this apparent departure from conservative behaviour increases with enhanced ice-rafted debris (IRD) fluxes has resulted in the suggestion that IRD leads to the overprinting of bottom water $\varepsilon \mathrm{Nd}$ through reversible scavenging. In this study, a simple water column model successfully reproduces $\varepsilon \mathrm{Nd}$ reconstructions from the eastern North Atlantic at the Last Glacial Maximum and Heinrich Stadial 1, and demonstrates that the changes in scavenging intensity required for good model-data fit is in good agreement with changes in the observed IRD flux. Although uncertainties in model parameters preclude a more definitive conclusion, the results indicate that the suggestion of IRD as a source of non-conservative behaviour in the $\varepsilon \mathrm{Nd}$ tracer is reasonable and that further research into the fundamental chemistry underlying the marine neodymium cycle is necessary to increase confidence in assumptions of conservative $\varepsilon \mathrm{Nd}$ behaviour in the past.
\end{abstract}

Keywords Neodymium isotopes · $\varepsilon$ Nd · Ice-rafted debris · IRD · Last Glacial Maximum · LGM · Heinrich event . Palaeoceanography $\cdot$ Paleoceanography $\cdot$ Model $\cdot$ Reversible scavenging $\cdot$ Conservative $\cdot$ Ocean circulation $\cdot$ Atlantic meridional overturning circulation $\cdot$ Geochemical cycling

\section{Introduction}

Ocean circulation constitutes a major component of global surface heat transport (Ganachaud and Wunsch 2000) and, as such, plays a significant role in determining the Earth's climate. However, despite improvements in our understanding of the role of the oceans in climate, significant uncertainty remains regarding how the oceans behave as a climate feedback (Marshall et al. 2015), particularly in the context of future climate predictions in response to anthropogenic forcings (e.g. Cheng et al. 2013). To resolve this uncertainty, one approach is to unravel the role ocean circulation plays in abrupt climate variability of the past. Of particular interest is

Noam Vogt-Vincent

noam.vogt-vincent@st-annes.ox.ac.uk

1 Department of Earth Sciences, University of Oxford, Oxford, UK

2 Institute of Earth Sciences, Heidelberg University, Heidelberg, Germany

3 Institute of Geosciences, University of Potsdam, Potsdam, Germany variability in the Atlantic meridional overturning circulation (AMOC), a major influencer of the climate of the North Atlantic and the rest of the globe (e.g. Jackson et al. 2015), as AMOC transport can be significantly reduced under high freshwater fluxes to regions of deep water formation (e.g. Zhang and Delworth 2005; Stouffer et al. 2006).

At present, the zonally integrated AMOC comprises a strong upper overturning cell ventilated from the north by deep water formation in the subpolar North Atlantic and marginal seas (North Atlantic Deep Water, NADW), overlaying a weaker overturning cell ventilated by dense bottom waters from the Southern Ocean (present in the eastern North Atlantic as Lower Deep Water, LDW, a highly modified Antarctic Bottom Water), with a boundary between the two zonally averaged cells in the North Atlantic at a depth of c. 3.5-4 km (Buckley and Marshall 2015), although it is somewhat shallower in the eastern North Atlantic at about $3 \mathrm{~km}$ depth (van Aken 2000). When considering deep and bottom water masses in the eastern North Atlantic, one can therefore distinguish between water masses originating from the north (northern-sourced water, NSW) in the form of NADW today and those originating from the south (southern-sourced water, 
SSW) in the form of LDW. It is important to note that there is considerable horizontal structure to the AMOC that is obfuscated by this zonally averaged view, with the main component of meridional transport in the North Atlantic occurring along the western boundary (Buckley and Marshall 2015).

Two time periods of particular interest for unravelling the role of ocean circulation in abrupt climate variability are the Last Glacial Maximum (LGM) and Heinrich Stadial 1 (HS1). Despite considerable ongoing discussion, there is a general consensus that Atlantic overturning at the LGM was shallow (e.g. Curry and Oppo 2005; Marchitto and Broecker 2006; Lippold et al. 2016) and strong (e.g. Praetorius et al. 2008; Böhm et al. 2015; Freeman et al. 2016), with an active, shoaled upper cell and an expanded, sluggish lower cell (e.g. Freeman et al. 2016; Lippold et al. 2016). Estimates for the extent of shoaling vary from a kilometre or more (Oppo and Lehman 1993; Marchitto and Broecker 2006) to unchanged from Holocene values (Gebbie 2014).

The extent of different water masses can be tracked through palaeotracers, principally in the form of nutrient tracers such as (foraminiferal) $\delta^{13} \mathrm{C}$ (Curry and Oppo 2005), radiocarbon (e.g. Thornalley et al. 2011) and $\mathrm{Cd} / \mathrm{Ca}$ ratios (e.g. Rickaby and Elderfield 2005). Recently, however, an inorganic tracer in the form of neodymium isotopes (expressed using the $\varepsilon \mathrm{Nd}$ notation) has come into widespread use (e.g. Arsouze et al. 2009; Piotrowski et al. 2012; Rempfer et al. 2012; Roberts and Piotrowski 2015; Pöppelmeier et al. 2018). In contrast to nutrient tracers, $\varepsilon \mathrm{Nd}$ is assumed to behave quasi-conservatively in the oceans (Jones et al. 2008; van de Flierdt et al. 2016).

However, this assumption of quasi-conservative behaviour is equivocal. Neodymium enters the oceans in dissolved and particulate phases through continental runoff and atmospheric fallout, and, like many other trace elements, is scavenged in the water column through adsorption onto particulates. This results in a mean ocean residence time on the order of hundreds of years (Tachikawa et al. 2003; Arsouze et al. 2007), although a recent study puts the figure at closer to 100 years (Hayes et al. 2018). However, adsorbed neodymium can also undergo desorption, resulting in continuous exchange between adsorbed $\left(\mathrm{Nd}_{\text {ads }}\right)$ and dissolved $\left(\mathrm{Nd}_{\mathrm{d}}\right)$ neodymium reservoirs as particles settle through the water column, in a process called reversible scavenging (Bacon and Anderson 1982).

The potential significance of localised highly nonconservative behaviour of neodymium isotopes for palaeoceanography has been raised by recent geochemical studies on sediment cores from the eastern North Atlantic (Roberts and Piotrowski 2015; Blaser et al. 2019). The extensive sea-ice in the North Atlantic during the last glaciation resulted in the widespread deposition of ice-rafted debris (IRD). Layers of exceptionally high IRD content originating from the Laurentide Ice Sheet were termed Heinrich Layers, representing depositional events during the last glacial and deglaciation known as Heinrich Stadials (Heinrich 1988;
Broecker et al. 1992), most recently Heinrich Stadial 1 and 2 at c. $17 \mathrm{ka}$ and $24 \mathrm{ka}$ BP respectively (Fig. 1). During these Heinrich Stadials (HS), the IRD flux in the northeast Atlantic exceeded the ambient flux during the last glacial by up to an order of magnitude (McManus et al. 1998; Haapaniemi et al. 2010; Obrochta et al. 2012). Furthermore, there is a strong consensus that overturning in the upper (northern) cell was considerably reduced during HS1 (McManus et al. 2004; Bradtmiller et al. 2014; Lynch-Stieglitz et al. 2014).

Roberts and Piotrowski (2015) found very high (radiogenic) $\varepsilon \mathrm{Nd}$ throughout the water column in the eastern North Atlantic during deglaciation. Blaser et al. (2019) extended this study and suggested that the underlying SSW appeared to have developed a $\mathrm{Nd}$ isotopic signature similar to that of overlying NSW. Both authors concluded that these observations are challenging to interpret under assumptions of conservative behaviour (Fig. 2), with Roberts and Piotrowski (2015) suggesting that dissolution of radiogenic IRD could be the cause. Blaser et al. (2019) found that vertical $\varepsilon \mathrm{Nd}$ profiles during exceptionally high IRD flux regimes such as Heinrich Stadials (HSs) deviated even further from a hypothetical conservative profile and argued that IRD may instead act as a vertical shuttle for neodymium, leading to the overprinting of abyssal SSW neodymium isotopic signatures with signals from further up in the water column through an acceleration of reversible scavenging. This suggestion is bolstered by additional recent observations of apparently nonconservative behaviour of $\varepsilon \mathrm{Nd}$ in high sediment flux regions, e.g. in the deep waters in the modern Panama Basin (Grasse et al. 2017) and Bay of Bengal (Yu et al. 2017).

Since most interpretations of neodymium isotopes as a palaeotracer operate under assumptions of dominantly conservative behaviour, it is crucial to check the viability of this assumption. The key hypothesis we investigate is therefore this - could geologically reasonable fluxes of IRD result in a dominant vertical transport of $\mathrm{Nd}$ and thus the overprinting of bottom water $\varepsilon \mathrm{Nd}$ signatures? In this paper, we present new palaeoenvironmental data from the Me68-89 sediment core (Blaser et al. 2019). We then present results from a simple proof-of-concept box model for neodymium reversible scavenging in order to constrain the hypothetical magnitude of scavenging required to alter the $\varepsilon \mathrm{Nd}$ signal accordingly.

\section{Materials and methods}

\section{Sediment cores}

As detailed in Blaser et al. (2019), three cores from the Dreizack seamount (Me68-91, Me68-89 and Po08-23) are combined with BOFS $5 \mathrm{~K}, 8 \mathrm{~K}, 10 \mathrm{~K}$ and $11 \mathrm{~K}$, and IODP Site U1308 at a morphological high in the Maury Channel, spanning a depth range of $3547-4470 \mathrm{~m}$ between $47-53^{\circ} \mathrm{N}$. HS1 
Fig. 1 Lithic grain counts from DSDP 609 (eastern North Atlantic) across HS1 and HS2 compared to the intervening LGM (dashed) and a 2 ka moving average (solid) (adapted from Bond et al. 2012)

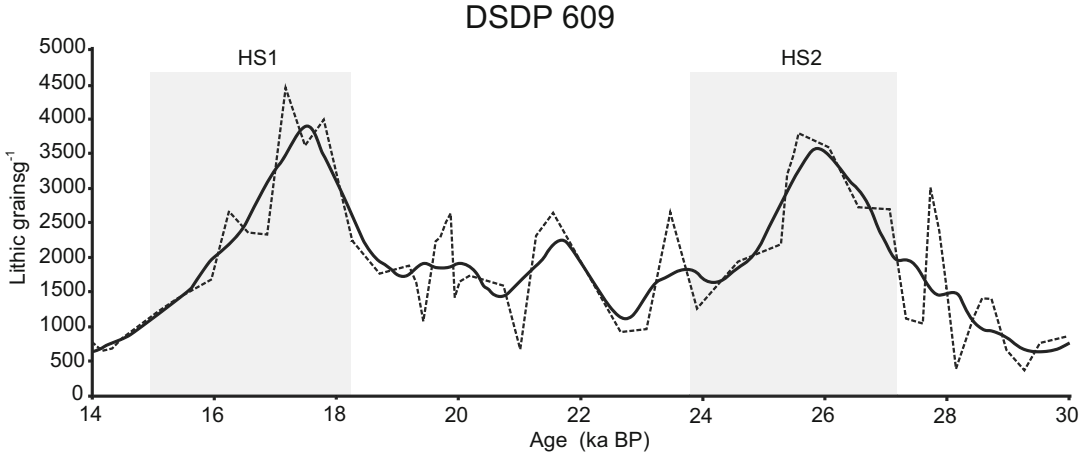

and HS2 are prominent in all cores and this paper specifically focuses on HS1, which has been further subdivided into a Hudson Strait event (represented by Heinrich Layer 1a) and a 'European' precursor (HLlb) (Blaser et al. 2019), which is identifiable as a detrital layer in these cores. $\varepsilon \mathrm{Nd}$ leachate data from Me68-89 (Blaser et al. 2019) reveals the large radiogenic excursion centred towards the end of HL1a. As discussed by Blaser et al. (2019), the $\varepsilon \mathrm{Nd}$ recorded at Me68-89 during HS1 is comparable to the records from other cores from below $3.5 \mathrm{~km}$ depth, as part of an apparent homogenisation of the abyssal $\varepsilon \mathrm{Nd}$ signature.

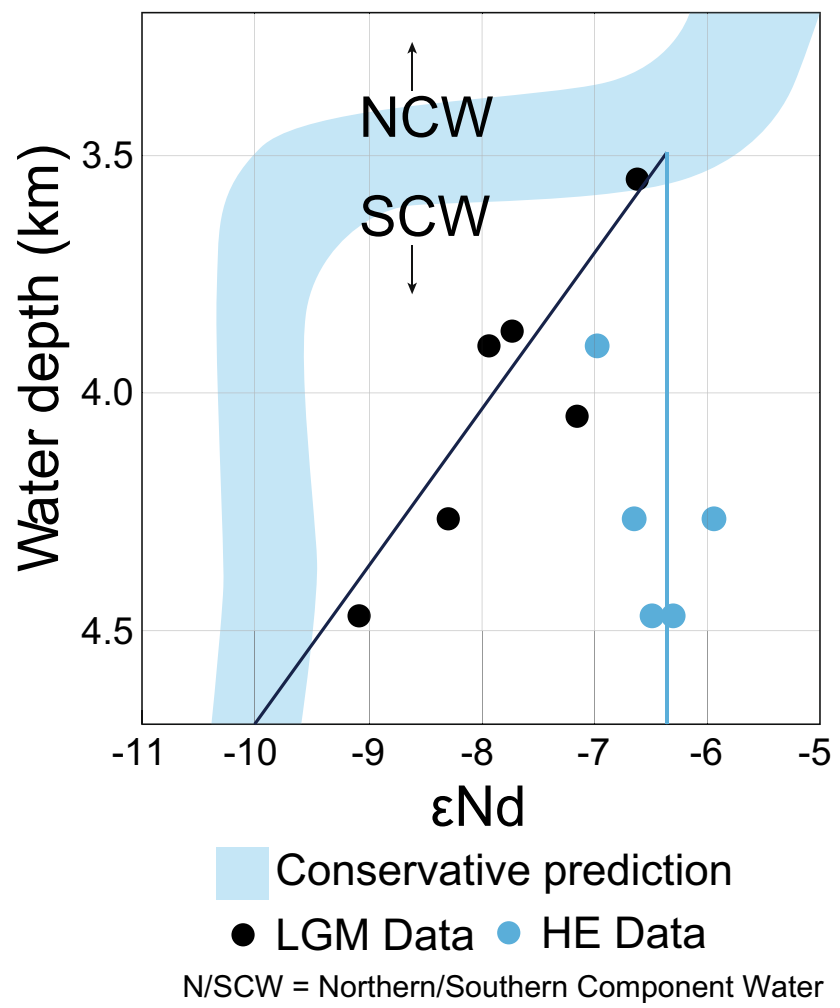

Fig. $2 \varepsilon N d$ reconstructions from the Dreizack Seamount at the LGM (dark blue) and HE1b/2b (light blue), adapted from Blaser et al. (2019) Fig. 8. The predicted locations and water mass boundary between northern and southern component waters (North Atlantic Deep Water $[\mathrm{NADW}]$ and Atlantic Bottom Water $[\mathrm{ABW}]$ respectively) and a predicted 'conservative' $\varepsilon \mathrm{Nd}$ profile are included
Here, to complement $\varepsilon$ Nd measurements from Me68-89, IRD and planktonic foraminifera counts were made from the washed $>63 \mu \mathrm{m}$ fraction at $1 \mathrm{~cm}$ intervals spanning HS1.

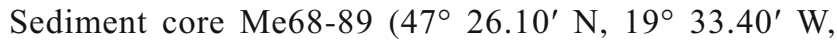
$4260 \mathrm{~m}$ water depth) is a core of intermediate depth at the Dreizack Seamount and is therefore relatively unaffected by turbidite flows in comparison to core Me68-91 (Blaser et al. 2019). IRD counts were subdivided into the four key lithologies identified: unstained quartz clasts, haematite-stained quartz clasts, mafic volcanic clasts and carbonate clasts. The total number of planktonic foraminifera $(p f)$ was counted, as well as Neogloboquadrina pachyderma sinistral (NPS).

\section{Model design}

\section{Overview}

The processes included in our model and key domain parameters and boundary conditions are summarised in Fig. 3 and Table 1 . The model broadly follows the approach of Luo et al. (2010). The model represents an area of dimensions $600 \times 600 \mathrm{~km}$ in the eastern North Atlantic. The neodymium concentration $[\mathrm{Nd}]\left(\mathrm{pmol} \mathrm{kg}^{-1}\right)$ and neodymium isotopic composition $\varepsilon \mathrm{Nd}$ are calculated for a vertical array of boxes representing the water column. In each box, there are two reservoirs of neodymium, dissolved $\left(\mathrm{Nd}_{\mathrm{d}}\right)$ and adsorbed $\left(\mathrm{Nd}_{\mathrm{ads}}\right)$, which exchange with adsorption and desorption rate constants of $K$ and $K^{-}\left(\mathrm{s}^{-1}\right)$ respectively, and are also influenced by advection. The adsorbed reservoir sinks through the water column due to particulate settling, transferring the $\mathrm{Nd}_{\mathrm{ads}}$ signal downwards. There is no vertical component of advection, but vertical exchange of the dissolved reservoirs is possible through vertical diffusion. Sediment settling out of the water column enters a sediment box, where it can then exchange with a pore water-dissolved neodymium reservoir through a particle concentration factor $f_{c}$ and particulate dissolution fraction $f_{p}$. This pore water can interact with the water column through a benthic 'piston velocity' $w^{*}\left(\mathrm{~m} \mathrm{~s}^{-1}\right)$, used by Abbott et al. (2015) to relate pore water fluxes into the water column to overlying [Nd]. Finally, sediment entering the water column from the surface can be 'pre-loaded' with 
neodymium. These processes are schematically represented in Fig. 4. The model integrates the equations below to steady state, with constants and variables defined in Table 1.

$$
\begin{aligned}
\frac{\partial}{\partial \boldsymbol{t}}[\mathbf{N d}]_{i}^{d}=\frac{v_{i}^{*}}{\widehat{y}} & \left\{[\mathrm{Nd}]_{b}^{d}-[\mathrm{Nd}]_{i}^{d}\right\}+K^{-}[\mathrm{Nd}]_{i}^{a d s}-K[\mathrm{Nd}]_{i}^{d} \\
& +\frac{1}{\widehat{z}}\left(\widehat{J}_{i}-\check{J}_{i}\right)+\delta_{z=0} \frac{w^{*}}{\widehat{y}}[\mathrm{Nd}]_{b}^{d} \\
\frac{\partial}{\partial \boldsymbol{t}}[\mathbf{N d}]_{i}^{a d s}= & \frac{v_{i}^{*}}{\widehat{y}}\left\{[\mathrm{Nd}]_{b}^{a d s}-[\mathrm{Nd}]_{i}^{a d s}\right\} \\
& +\frac{s_{i}^{*}}{\widehat{z}}\left\{[\mathrm{Nd}]_{i-1}^{a d s}-[\mathrm{Nd}]_{i}^{a d s}\right\}+K[\mathrm{Nd}]_{i}^{d}-K^{-}[\mathrm{Nd}]_{i}^{a d s} \\
& +\delta_{\text {seabed }} \frac{s^{*}}{\widehat{z}}[\mathrm{Nd}]_{b}^{a d s}
\end{aligned}
$$

$$
\begin{aligned}
{[\mathrm{Nd}]_{i}^{d} \frac{\partial}{\partial \boldsymbol{t}} \varepsilon \mathbf{N d}_{i}^{d}=} & \frac{v_{i}^{*}}{\widehat{y}}\left\{[\mathrm{Nd}]_{b}^{d} \varepsilon N d_{b}^{d}-[\mathrm{Nd}]_{i}^{d} \varepsilon \mathrm{Nd}_{i}^{d}\right\} \\
& +K^{-}[\mathrm{Nd}]_{i}^{a d s} \varepsilon \mathrm{Nd}_{i}^{a d s}-K[\mathrm{Nd}]_{i}^{d} \varepsilon \mathrm{Nd}_{i}^{d} \\
& +\frac{1}{\widehat{z}} \widehat{J}_{i} \varepsilon \mathrm{Nd}_{i-1^{+}, i^{-}}^{d}-\frac{1}{\widehat{z}} J_{i} \varepsilon \mathrm{Nd}_{i^{+}, i+1^{-}}^{d} \\
& +\delta_{z=0} \frac{w^{*}}{\widehat{y}}[\mathrm{Nd}]_{b}^{d} \varepsilon \mathrm{Nd}_{b}^{d}+\Delta_{i}^{d}
\end{aligned}
$$

$$
\begin{aligned}
{[\mathrm{Nd}]_{i}^{a d s} \frac{\partial}{\partial t} \varepsilon \mathbf{N d}_{i}^{a d s}=} & \frac{v_{i}^{*}}{\widehat{y}}\left\{[\mathrm{Nd}]_{b}^{a d s} \varepsilon \mathrm{Nd}_{b}^{a d s}-[\mathrm{Nd}]_{i}^{a d s} \varepsilon \mathrm{Nd}_{i}^{a d s}\right\} \\
& +\frac{s^{*}}{\widehat{z}}\left\{[\mathrm{Nd}]_{i-1}^{a d s} \varepsilon \mathrm{Nd}_{i-1}^{a d s}-[\mathrm{Nd}]_{i}^{a d s} \varepsilon \mathrm{Nd}_{i}^{a d s}\right\} \\
& +K[\mathrm{Nd}]_{i}^{d} \varepsilon \mathrm{Nd}_{i}^{d}-K^{-}[\mathrm{Nd}]_{i}^{a d s} \varepsilon \mathrm{Nd}_{i}^{a d s} \\
& ++\delta_{\text {seabed }} \frac{s^{*}}{\widehat{z}}[\mathrm{Nd}]_{b}^{a d s} \varepsilon \mathrm{Nd}_{b}^{a d s}+\Delta_{i}^{a d s}
\end{aligned}
$$

where $\Delta_{i}^{x}=-\varepsilon \mathrm{Nd}_{i}^{x} \frac{\partial}{\partial t}[\mathrm{Nd}]_{i}^{x} \sim 0$ at equilibrium.

\section{Velocity profile}

A synthetic velocity (advection) profile is used, representing the key characteristics of mean advection profiles during the LGM. This profile is presented in Fig. 5. Constraints on the LGM water column velocity profile in the eastern North Atlantic are poor, so the 'LGM-like' profile reflects the hypothesis that overturning during the LGM was strong and shoaled versus the modern (e.g. Lippold et al. 2012). There is however debate regarding the extent of shoaling. Many studies, particularly those based on nutrient proxies, have argued for a significant shoaling of the NSW-SSW interface up to 2000-2500 m (e.g Curry and Oppo 2005; Marchitto and Broecker 2006; Lippold et al. 2016). However, it has been argued that nutrient proxies exaggerate the extent of shoaling (Gherardi et al. 2009; Lippold et al. 2012; Gebbie 2014; Howe et al. 2016a), and that there was strong stratification between NSW and SSW, contrary to simple mass-balance estimates from $\delta^{13} \mathrm{C}$ (Yu et al. 2008; Gebbie 2014). It is also likely that the extent of shoaling may have been spatially variable, for instance a shallower boundary at the Rockall Plateau than the central basin (e.g. van Aken 2000). We therefore take a more conservative view here with a glacial NSW-SSW boundary at $3500 \mathrm{~m}$, albeit with the recognition that this figure is uncertain (as with the entire advection profile). For comparison, a synthetic 'shoaled' LGM profile has also been produced with a NSW-SSW boundary at $2500 \mathrm{~m}$. These LGM profiles are normalised to represent the same overturning strength as the late Holocene profile, in line with the general consensus that net LGM overturning strength was similar to today (Yu et al. 1996; McManus et al. 2004).

Constraints on circulation during Heinrich Stadials are similarly poor. Whilst early evidence was interpreted as representing an AMOC cessation (e.g. McManus et al. 2004), it has since become clear that overturning continued, albeit significantly weakened (Bradtmiller et al. 2014; LynchStieglitz et al. 2014; Wilson et al. 2014; Chen et al. 2015; Wei et al. 2016). To simulate a HS, the LGM-like advection velocity profile is scaled by a factor of 0.2 to represent qualitatively similar but significantly weakened circulation (Fig. 5).

\section{Scavenging rates}

Exchange between the dissolved and adsorbed reservoirs is assumed to be proportional to adsorption and desorption rate constants, following the approach of Luo et al. (2010). At equilibrium, in a static water column:

$$
\begin{aligned}
& K[\mathrm{Nd}]_{\mathrm{d}}=K^{-}[\mathrm{Nd}]_{\mathrm{ads}} \\
& K_{\text {eqm }}=\frac{K}{K^{-}}=\frac{[\mathrm{Nd}]_{\mathrm{ads}}}{[\mathrm{Nd}]_{\mathrm{d}}}
\end{aligned}
$$

\section{(concentrations are per unit mass of water)}

The ratio $K_{\text {eqm }}$ therefore gives the distribution of $\mathrm{Nd}$ between the dissolved and adsorbed reservoirs at equilibrium. For example, if $K=K$, at equilibrium $\mathrm{Nd}$ will be equally distributed between the dissolved and adsorbed reservoirs. Note that since all concentrations are per unit mass of water, the concentration of $\mathrm{Nd}$ in the adsorbed phase will be $\frac{1}{\alpha}[\mathrm{Nd}]_{\mathrm{ads}}$ where $\alpha$ is the adsorbed particulate mass fraction. In the absence of empirical constraints, it is assumed that $K=K$.

Since scavenging is assumed to be the only Nd sink in this model, at steady state and in the absence of advection, the scavenging rates correspond to the residence time of $\mathrm{Nd}$ in the water column, i.e.

$[\mathrm{Nd}]_{\mathrm{d}}(t)=[\mathrm{Nd}]_{\mathrm{d}}^{0} e^{-K t}$ 
Fig. 3 a The key dynamical processes involved in the cycling of neodymium in the open glacial and deglaciating ocean, integrated into the model. b Boundary conditions relevant to the eastern North Atlantic during the glacial and deglaciating ocean, including model domain dimensions and a schematic velocity profile
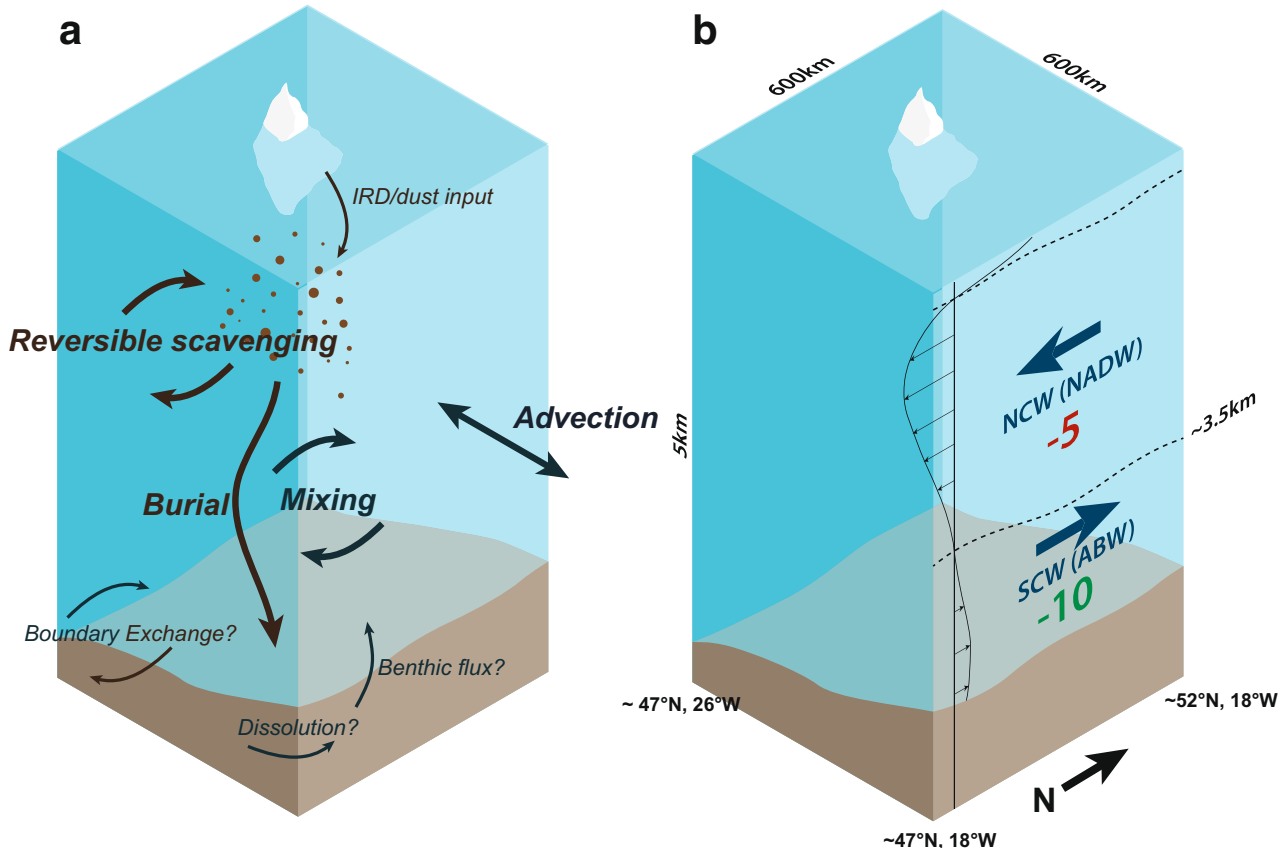

It is important to note that $K$ is not a material property, it is a bulk parameterisation for all the factors that impact the rate of exchange of $\mathrm{Nd}$ between the dissolved and adsorbed reservoirs. Therefore, $K$ will be a function of material adsorption and desorption rates for the various components that make up IRD, as well as the IRD concentration in the water column. $K$ and $K$ are not necessarily equal and may vary as a function of time there are no constraints on this variability. Furthermore, the scavenging rate is assumed to be directly proportional to particle concentration, although this is debatable (Tachikawa et al. 1997). It is assumed that particle concentration is proportional to particle flux, which relies on constant settling rate and therefore constant particle size. Here, only one average type of particle is modelled. Given the mineralogy of IRD (e.g. Hodell et al. 2017), IRD particles are assumed not to dissolve over settling timescales, that is to say that $\mathrm{Nd}$ exchange between particles and the water column is restricted to scavenging
Table 1 Model variables (and constant values) for simulations

\begin{tabular}{|c|c|c|}
\hline \multicolumn{3}{|c|}{ Model variables } \\
\hline Symbol & Variable & Constant values \\
\hline$\widehat{X}, \widehat{Y}, \widehat{Z}$ & Domain dimensions $(\mathrm{m})$ & $6 \times 10^{5} \mathrm{~m}, 6 \times 10^{5} \mathrm{~m}, 5 \times 10^{3} \mathrm{~m}$ \\
\hline$\widehat{x}, \widehat{y}, \widehat{z}$ & Cell dimensions $(\mathrm{m})$ & $6 \times 10^{5} \mathrm{~m}, 6 \times 10^{5} \mathrm{~m}, 1 \times 10^{2} \mathrm{~m}$ \\
\hline$[\mathrm{Nd}]_{i}^{x}$ & $\begin{array}{l}\text { Nd concentration in cell } i \text { ( } b \text { is a boundary condition } \\
\text { at } i \text { ) and phase } x \text {, which is either dissolved }(d) \text { or } \\
\text { adsorbed }(a d s)\left({\text { pmol } \mathrm{kg}_{\mathrm{w}}}^{-1}\right)\end{array}$ & \\
\hline$\varepsilon \mathrm{Nd}_{i}^{x}$ & $\begin{array}{l}\mathrm{Nd} \text { isotopic ratio }(\varepsilon \mathrm{Nd}) \text { in cell } i \text { ( } b \text { is a boundary } \\
\text { condition at } i) \text { and phase } x \text { (no units) }\end{array}$ & \\
\hline$v_{i}^{*}$ & Horizontal velocity $\left(\mathrm{m} \mathrm{s}^{-1}\right)$ & \\
\hline$s^{*}$ & Sinking rate $\left(\mathrm{m} \mathrm{s}^{-1}\right)$ & $3 \times 10^{-5} \mathrm{~m} \mathrm{~s}^{-1} \approx 1 \times 10^{3} \mathrm{~m} \mathrm{a}^{-1}$ \\
\hline$w^{*}$ & Piston velocity $\left(\mathrm{m} \mathrm{s}^{-1}\right)$ & 0 or $3 \cdot 10^{-7} \mathrm{~m} \mathrm{~s}^{-1}$ \\
\hline$D_{i}$ & Diffusivity in cell $i\left(\mathrm{~m}^{2} \mathrm{~s}^{-1}\right)$ & $10^{-5}-5 \times 10^{-4} \mathrm{~m}^{2} \mathrm{~s}^{-1}$ \\
\hline$\hat{J}_{i}$ & $\begin{array}{l}-\frac{D}{\widetilde{z}}\left([\mathrm{Nd}]_{i}^{d}-[\mathrm{Nd}]_{i-1}^{d}\right) \text {, i.e. net diffusive flux at lower } \\
\quad \text { boundary }\left(\mathrm{pmol} \mathrm{m}^{-2} \mathrm{~s}^{-1}\right)\end{array}$ & \\
\hline$\check{J}_{i}$ & $\begin{array}{l}-\frac{D}{\widehat{z}}\left([\mathrm{Nd}]_{i+1}^{d}-[\mathrm{Nd}]_{i}^{d}\right), \text { i.e. net diffusive flux at lower } \\
\quad \text { boundary }\left(\mathrm{pmol} \mathrm{m}^{-2} \mathrm{~s}^{-1}\right)\end{array}$ & \\
\hline$K_{i}$ & Adsorption rate in cell $i\left(\mathrm{~s}^{-1}\right)$ & \\
\hline $\mathrm{K}_{i}^{-}$ & Desorption rate in cell $i\left(\mathrm{~s}^{-1}\right)$ & \\
\hline$\delta_{z=i}$ & Delta function for cell $I$ & \\
\hline
\end{tabular}




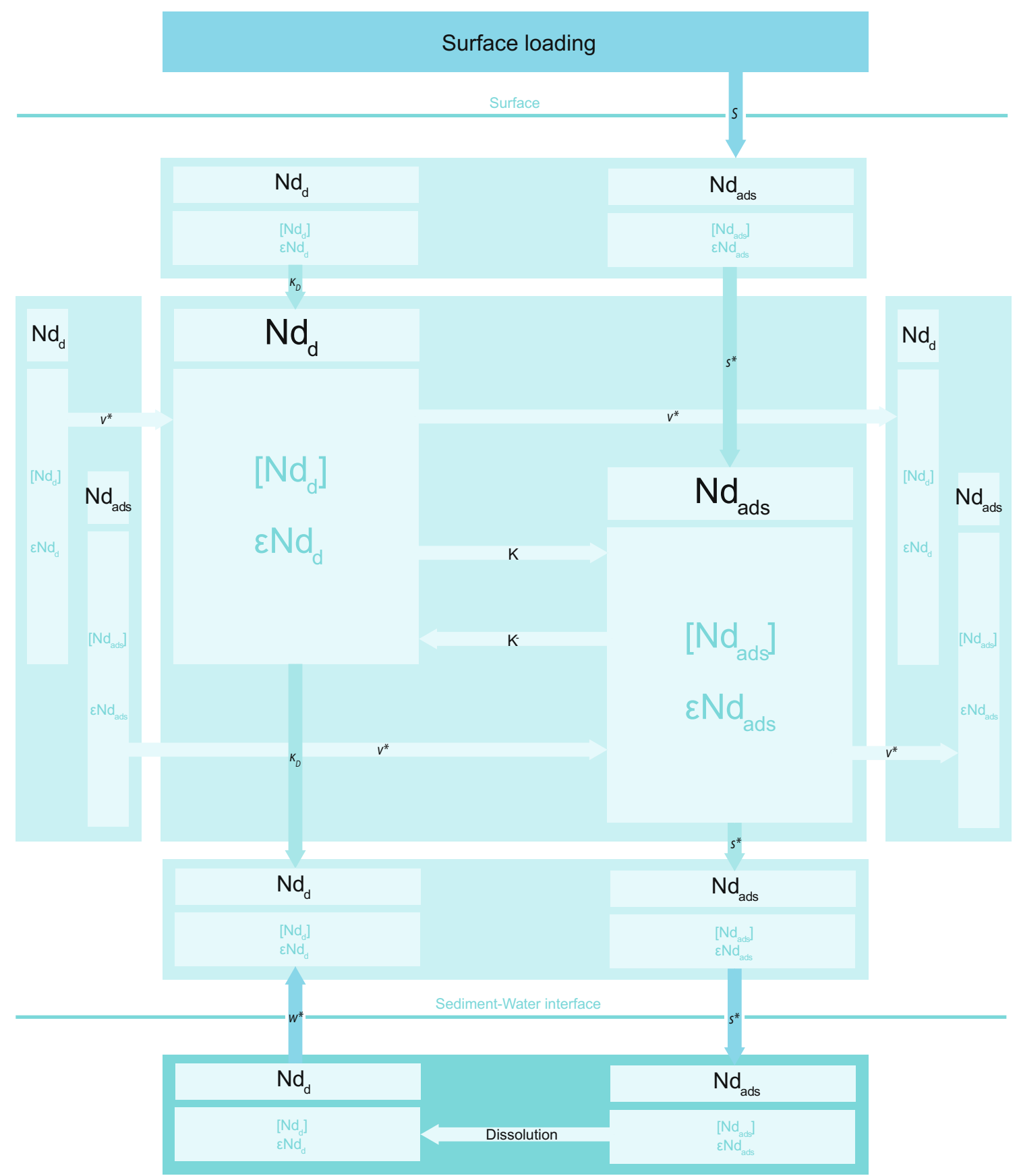

Fig. 4 The model consists of 50 vertical boxes of dimensions $\left[5 \times 10^{3} \mathrm{~m} \times 6 \times 10^{6} \mathrm{~m} \times 6 \times 10^{6} \mathrm{~m}\right]$. Within each box is a dissolved $\left(\mathrm{Nd}_{\mathrm{d}}\right)$ and adsorbed $\left(\mathrm{Nd}_{\mathrm{ads}}\right)$ neodymium reservoir, for which concentration $[\mathrm{Nd}]\left(\mathrm{pmol} \mathrm{kg}{ }^{-1}\right.$ water $)$ and isotopic composition $\varepsilon \mathrm{Nd}$ are stored. See Table 1 for fluxes

interactions on particle surfaces as opposed to bulk particle dissolution.

\section{Boundary conditions}

Boundary conditions are based on Blaser et al. (2019). NSW and SSW are assumed to have constant $\varepsilon \mathrm{Nd}$ of -5 and -10 respectively, the former signature derived from Roberts and Piotrowski (2015) and Howe et al. (2016b). Concentration profiles are based on modern profiles from van de Flierdt et al. 2012. Specifically, both NSW and SSW $[\mathrm{Nd}]_{\mathrm{d}}$ increase linearly with depth from $15 \mathrm{pmol} \mathrm{kg}^{-1}$ at the surface to $25 \mathrm{pmol} \mathrm{kg}^{-1}$ at the seafloor. It is uncertain whether this would also be the case at the LGM but there is no good way of reconstructing palaeo- $[\mathrm{Nd}]_{\mathrm{d}}$ at present and the model $\varepsilon \mathrm{Nd}$ sensitivity to $[\mathrm{Nd}]_{\mathrm{d}}$ is quite low.

In the model runs below, it is assumed that all adsorbed $\mathrm{Nd}$ is sourced from adsorption within the model domain, i.e. no 
pre-loaded particle-reactive neodymium exists in particles entering the domain. The justifications for this assumption are (i) that the rate of scavenging within the IRD belt is significantly greater than outside the IRD belt and (ii) that scavenging only occurs at the surface of particles so there is no exchange between the dissolved $\mathrm{Nd}$ reservoir and detrital particulate $\mathrm{Nd}$.

\section{Results from Me68-89}

A peak in the detrital carbonate fraction as well as a minimum in the $p f: I R D$ ratio is centred around the previously established HL1a interval, validating these earlier results and representing a significant detrital carbonate IRD flux of Laurentide origin.

The planktonic foraminiferum Neogloboquadrina pachyderma sinistral (NPS) is an established proxy for polar sea-surface temperature (e.g. Ericson 1959; Kohfeld et al. 1996). The NPS (measured as a fraction of the total $p f$ count) data from Me68-89 (Fig. 6) is noisy and does not appear to characterise HL1a as is the case for the $p f: I R D$ ratio. If NPS faithfully represents cold SSTs and the $p f: I R D$ ratio represents the sediment dilution by the accompanying high IRD flux, these data would be expected to be negatively correlated; however, there is no statistically significant correlation. This could indicate that SST perturbations at site Me68-89 were not significant enough during HS1 to significantly impact the NPS abundance. There is nevertheless a generally declining trend from the peak glacial conditions preceding HL1b to the deglacial conditions postdating HLla, likely representing the ongoing trend of deglaciation in the eastern North Atlantic.

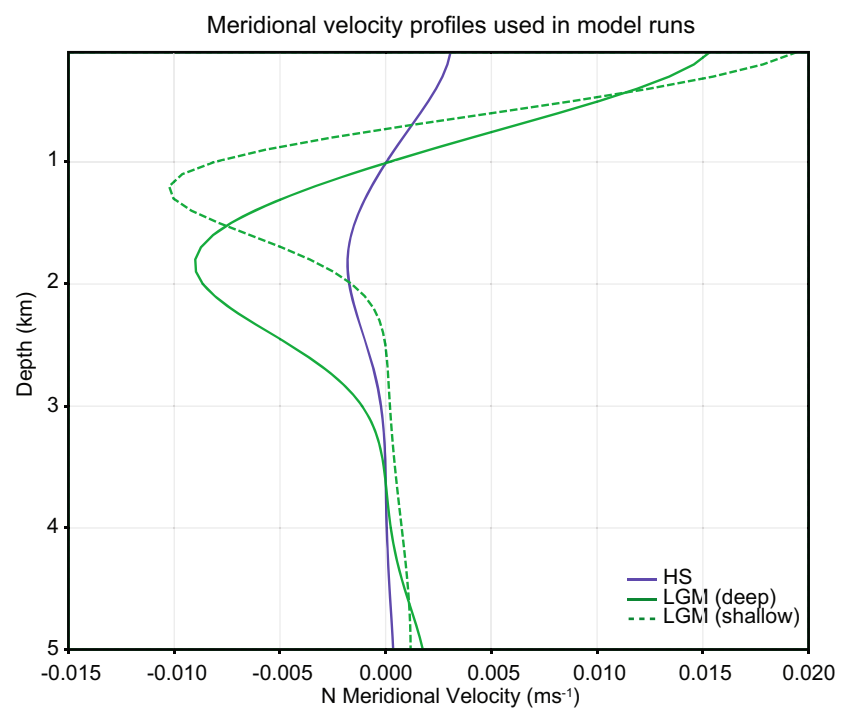

Fig. 5 Velocity profiles used in the model runs in this paper

\section{A simple scavenging model for the glacial and deglacial eastern North Atlantic}

Using our 'deep' (hereon default) LGM-like advection profile (Fig. 5) with the widely-assumed residence time of centuries (Tachikawa et al. 2003), a sharp boundary between northern and southern component water masses is reproduced, reflecting conservative behaviour (Figs. 2 and 7a), deviating significantly from the observations. It is possible to recreate the key features of the bottom water $\varepsilon \mathrm{Nd}$ profile as reported by Blaser et al. (2019), but only by setting the scavenging intensity to an equivalent residence time of $\tau=8$ years (Fig. 7b). This results in a gradual transition in $\varepsilon \mathrm{Nd}_{d}$ from close to -5 (the $\varepsilon \mathrm{Nd}_{\mathrm{d}}$ of the NSW, i.e. [glacial] North Atlantic Deep Water) at the NSW-SSW interface to -10 at a depth of $5000 \mathrm{~m}$. The $\varepsilon \mathrm{Nd}$ of the adsorbed reservoir $\left(\varepsilon \mathrm{Nd}_{\mathrm{ads}}\right)$ retains a NSW-like signature for longer, only reaching -7 at $5000 \mathrm{~m}$. Modeldata agreement is more challenging using the significantly shoaled LGM velocity profile, with the model struggling to achieve a steep enough $\varepsilon \mathrm{Nd}_{\mathrm{d}}$ gradient at abyssal depths (Fig. $7 \mathrm{c}$ ) and requiring a greater scavenging rate to do so.

To homogenise the bottom water $\varepsilon \mathrm{Nd}_{\mathrm{d}}$ and therefore recreate the reconstructed profiles for HS1/2 (Blaser et al. 2019), the scavenging intensity must be increased by approximately an order of magnitude, to an equivalent residence time of $\tau=$ 1 year (Fig. 7d). With such a low residence time, the dissolved and adsorbed reservoirs are close to equilibrium at all depths. Whilst these low residence times differ dramatically from assumed whole-ocean $\mathrm{Nd}$ residence times (Tachikawa et al. 2003), localised low residence times may be possible (see discussion, "Benthic Nd flux").

The effects of modifying the two key physical parameters of scavenging intensity and advection can be further explored by plotting the difference in $\varepsilon \mathrm{Nd}_{\mathrm{d}}\left(\Delta \varepsilon \mathrm{Nd}_{\mathrm{d}}\right)$ across the SSW layer $(3.5-5.0 \mathrm{~km})$ as a function of these two parameters (Fig. 8). In the LGM- and HS-like advection profiles, NSW and SSW carry a $\varepsilon \mathrm{Nd}_{\mathrm{d}}$ of -10 and -5 respectively, so perfectly conservative behaviour would result in a trans-SSW $\Delta \varepsilon \mathrm{Nd}_{\mathrm{d}}$ of -5 (e.g. close to Fig. $7 \mathrm{~b}$ ). Similarly, completely overprinting the bottom water $\varepsilon \mathrm{Nd}_{\mathrm{d}}$ with NSW-like $\varepsilon \mathrm{Nd}$ would result in a trans-SSW $\Delta \varepsilon \mathrm{Nd}_{\mathrm{d}}$ of 0 (e.g. close to Fig. $7 d)$. Figure 8 shows that in order to begin deviating from conservative behaviour, irrespective of advection strength, the residence time $\tau$ must fall below a few decades. Sensitivity to $\tau$ is greatest in the range $10^{0}-10^{1}$ yearswithin this range, relatively small changes in scavenging intensity can result in very significant changes in the water column $\varepsilon \mathrm{Nd}_{d}$ profile. Within the range plotted in Fig. $8, \varepsilon \mathrm{Nd}_{d}$ has a limited sensitivity to advection strength apart from at very high scavenging intensity.

Data-model misfit can also be explored within this parameter space, as shown in Fig. 9. These diagrams again strongly implicate an approximately order of magnitude increase in 
Me68-89

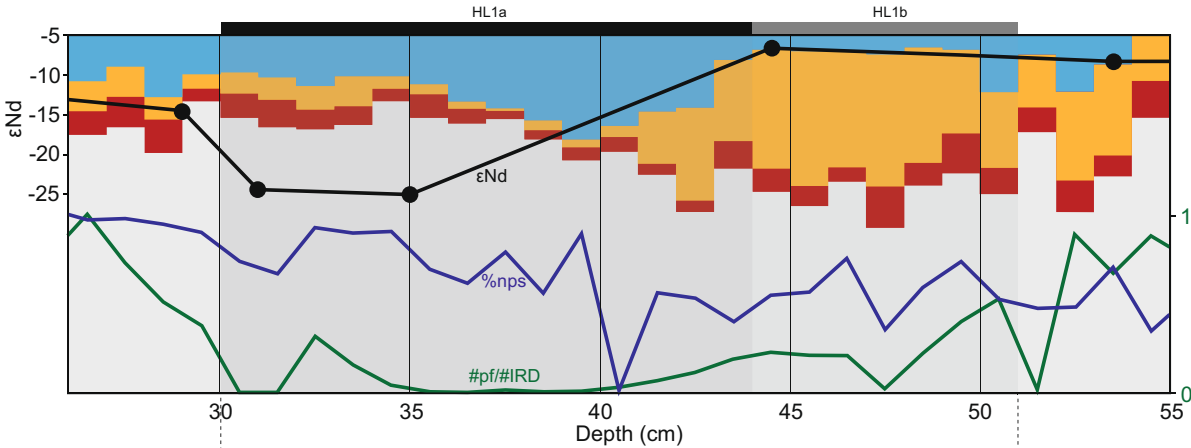

SU81-18 \& DSDP 609

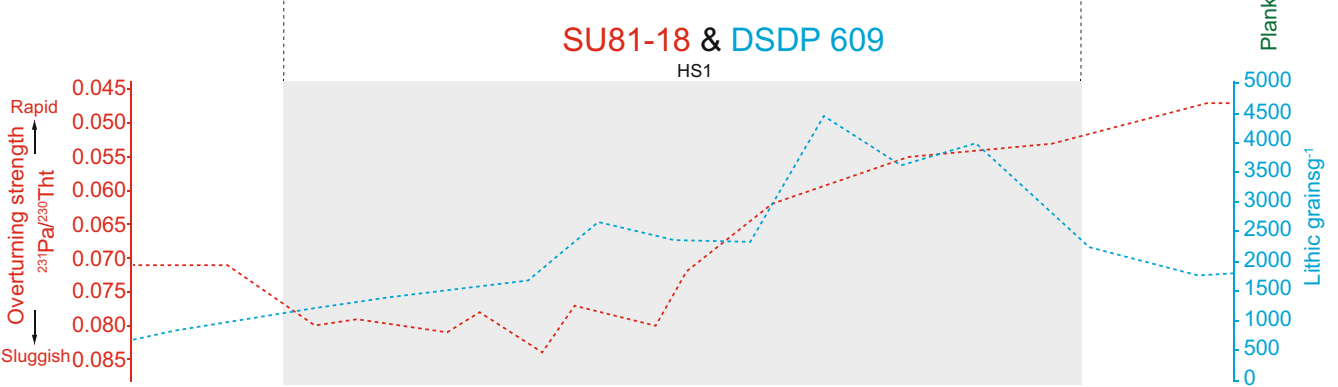

Fig. 6 IRD mineralogy in core Me68-89, normalised to unstained quartz (qz), haematite-stained quartz (haem), volcanic (volc) and carbonate (carb) fractions; $\varepsilon \mathrm{Nd}$ (Blaser et al. 2019); N. pachyderma $S$ proportion (\%nps); IRD-normalised planktonic foram count (\#pf/\#IRD). Also plotted for comparison is the ${ }^{231} \mathrm{~Pa} /{ }^{230} \mathrm{Th}$ record from the Iberian margin
SU81-18 site (Gherardi et al. 2005) and IRD counts from the eastern North Atlantic DSDP 609 site (Bond et al. 2012), which have been scaled to match the HS1 intervals identified from the three cores. However, these data are provided for qualitative comparison only as there is no precise age-model for Me68-89 scavenging rate to explain the differences between the reconstructed LGM and HS profiles. The advection strength corresponding to the lowest model-data misfit is not significantly different between the LGM and HS; however, at these points, the misfit is relatively insensitive to advection strength.

A similar method is used to investigate the assumptions made on the NSW/SSW interface depth (see "Velocity profile") by plotting data-model misfit as a function of interface depth and scavenging intensity (Fig. 10). The LGM data reveal a trade-off between interface depth and scavenging intensity. It is possible to get good data-model agreement across all reasonable interface depths; however, a shoaling of $1 \mathrm{~km}$ relative to $3.5 \mathrm{~km}$ requires an approximately order of magnitude increase in scavenging intensity, eroding any LGM-HS difference. The HS data also permit good data-model agreement across most reasonable interface depths and there is a weaker trade-off with scavenging intensity, unsurprising due to the simple structure implied by the HS data. These data are therefore not fundamentally incompatible with a shoaled NSW/ SSW interface; however, the implication is that a shoaled interface would require significantly greater scavenging rates at the LGM, which may be difficult to justify.

The bathymetry in the eastern North Atlantic is not flat and water column $\varepsilon \mathrm{Nd}_{\mathrm{d}}$ can only be recorded where a sediment-water interface exists. To test whether diagenetic remobilisation of adsorbed $\varepsilon \mathrm{Nd}$ within the sediment could alter the above results, a new diagenetic $\varepsilon \mathrm{Nd}$ profile is produced, $\varepsilon \mathrm{Nd}_{\text {diagenetic }}$. For this metric, IRD is assumed to be concentrated by a factor of $10^{3}$ in the sediment versus the water column and a remobilisation of $1 \%$ of adsorbed $\mathrm{Nd}$ to produce an altered diagenetic $\varepsilon \mathrm{Nd}$ signature. Blaser et al. (2019) did not find evidence of vertical migration of remobilised $\mathrm{Nd}$ within sediments, so we do not consider the vertical mixing of pore fluids. The results are presented in Fig. $11 \mathrm{a}$, b. The $\varepsilon \mathrm{Nd}_{\mathrm{ads}}$ has a greater 'inertia' with depth than the $\varepsilon \mathrm{Nd}_{\mathrm{d}}$ profile (i.e. it retains signals from overlying water masses for longer), so the $\varepsilon \mathrm{Nd}_{\text {diagenetic }}$ profile is an intermediate between the two. The best model-data fits for $\varepsilon \mathrm{Nd}_{\text {diagenetic }}$ require weaker scavenging than $\varepsilon \mathrm{Nd}_{\mathrm{d}}(\tau=40$ and 5 years for the LGM-like and HS-like profiles respectively) but the difference between these two residence times remains similar to the $\varepsilon \mathrm{Nd}_{\mathrm{d}}$ case, about an order of magnitude.

\section{Explanations for reconstructed $\varepsilon N d$ profiles}

The results of our model (Figs. 7, 8 and 9) indicate that, for IRD fluxes to drive significant non-conservative $\varepsilon \mathrm{Nd}$ behaviour, (1) the residence time of $\mathrm{Nd}$ in the glacial and deglaciating eastern North Atlantic would have to be on the order of decades at most and (2) an increase in scavenging intensity of approximately an order of magnitude is needed to 

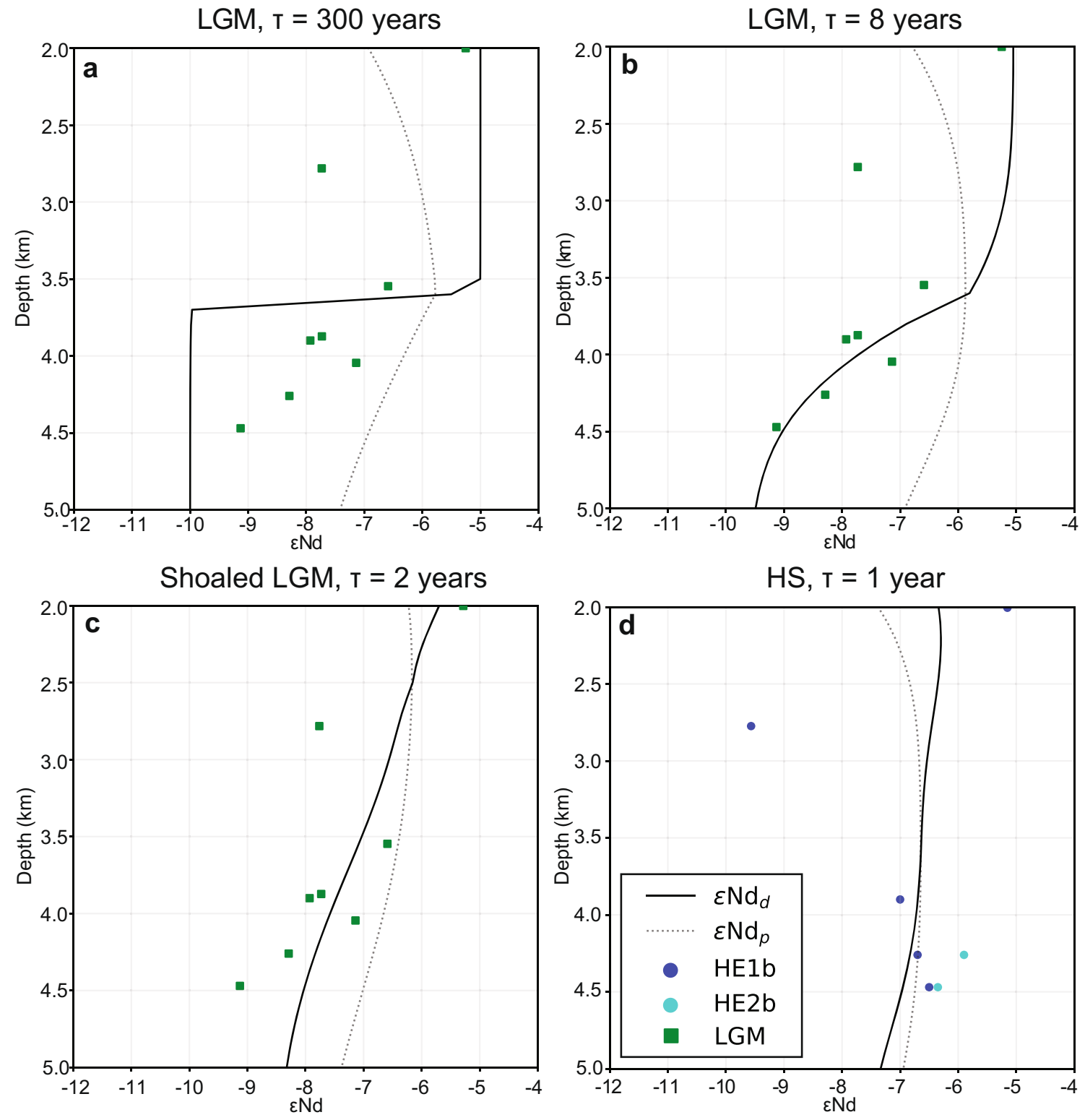

Fig. 7 Modelled steady-state $\varepsilon N d$ profiles, a with an LGM-like velocity profile (Fig. 5) with a residence time (scavenging intensity) $\tau=300$ years; b as with a but with $\tau=8$ years, tuned to fit the profile compiled by Blaser

et al. (2019) and Roberts and Piotrowski (2015) (data points); c with a shoaled LGM-like velocity profile (Fig. 5) and $\tau=2$ years; and $\mathbf{d}$ with a HS-like velocity profile (Fig. 5) and $\tau=1$ year

transition from an LGM-like profile to a HS-like profile. In the following, we discuss to what extent IRD is capable of causing this behaviour and whether the model results are reasonable and applicable to the glacial eastern North Atlantic.

\section{Conservative behaviour}

The null hypothesis is that $\varepsilon \mathrm{Nd}$ is behaving conservatively, and that the changes in the $\varepsilon \mathrm{Nd}$ profile between the LGM and HSs are therefore due to the movement of water masses and/or are an inherited property obtained from upstream changes in the $\varepsilon \mathrm{Nd}$ profile. However, advection of water masses cannot explain the highly gradational LGM $\varepsilon$ Nd profile (Fig. 2). The conservative interpretation of Fig. 2 would require a significant increase in the strength and depth of NSW in the eastern North Atlantic during Heinrich Stadials versus the LGM, the opposite of what other proxies suggest (e.g. McManus et al. 2004). Whilst there is evidence for significant NSW endmember $\varepsilon \mathrm{Nd}$ variability during the LGM and deglaciation (Roberts and Piotrowski 2015), this still cannot explain the partial and total absence of a SSW signature in bottom water $\varepsilon N d$ without either an expansion in NSW or SSW endmember $\varepsilon N d$ changing in lockstep. Therefore, it is difficult to find a reasonable justification for complete conservative interpretations for the observed glacial and deglacial $\varepsilon \mathrm{Nd}$ profiles at the Dreizack seamount of Blaser et al. (2019). 


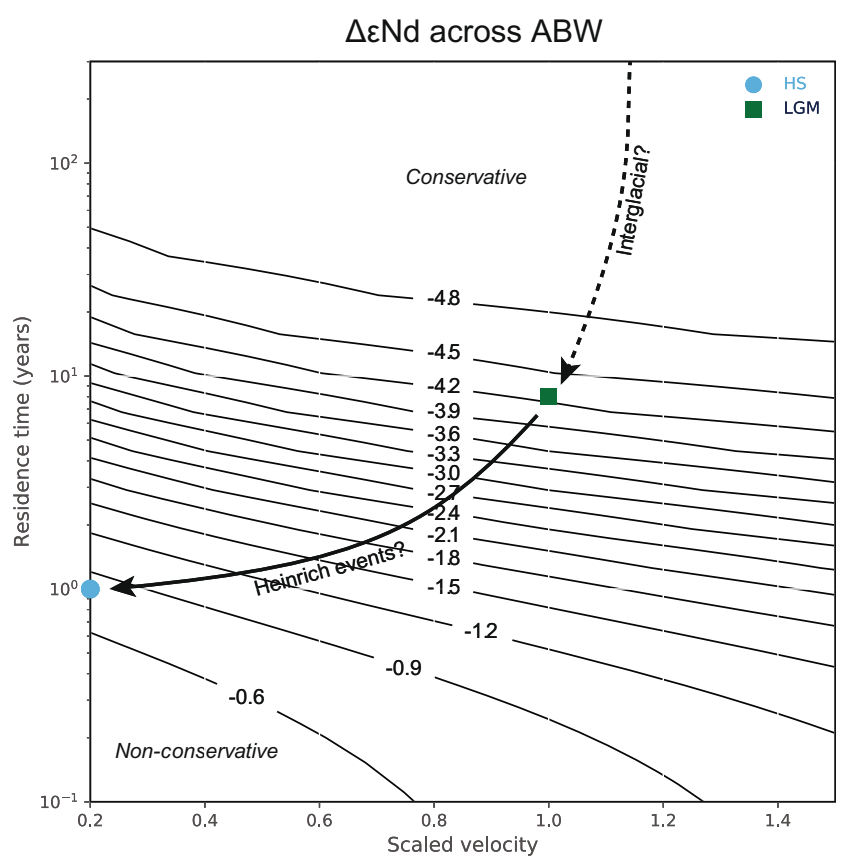

Fig. 8 Parameter space showing the effects of residence time (scavenging intensity) and scaled water velocity on bottom water overprinting. Scaled water velocity is relative to the LGM-like profile, i.e. $v_{L G M}=1$ and $v_{H S}=$ 0.2 . Contours show the $\varepsilon \mathrm{Nd}$ difference across the SSW, where -5 represents the advected profile (i.e. no overprinting, entirely conservative behaviour) and 0 represents total overprinting of the $\mathrm{ABW} \varepsilon \mathrm{Nd}$. Note that neither end-member is reached in this parameter space. Results from model runs in Fig. 7b, d are plotted in green and blue respectively

\section{Diffusion}

Whilst the LGM profile in Fig. 2 superficially resembles a diffusive boundary between two water masses, the (kilometre) scale of this trend cannot be reconciled with the strength of advection that acts to reinforce a sharp water mass boundary. Vertical diffusivity in the ocean is highly spatially variable, ranging from order $1 \times 10^{-5} \mathrm{~m}^{2} \mathrm{~s}^{-1}$ in the open ocean to over $5 \times 10^{-4} \mathrm{~m}^{2} \mathrm{~s}^{-1}$ above rough topography (Polzin et al. 1997; Toole et al. 1997). Since the $\varepsilon N d$ profile of Blaser et al. (2019) was collected from a seamount, it is feasible that diffusivity could reach the upper limits of this range. However, as demonstrated in Fig. 11c, d, even extreme values for diffusivity are unable to recreate the reconstructed LGM profile of Blaser et al. (2019). In any case, diffusion is unable to explain the homogenised water column reconstructed for HSs (Fig. 2). In the context of this problem, the only relevance of vertical diffusion is as a control on benthic $\mathrm{Nd}$ flux propagation into the water column ("Benthic Nd flux").

\section{Benthic Nd flux}

It has been suggested that fluxes of pore fluid into the water column (benthic flux) may act as an additional control on bottom water $\varepsilon N d$ in the Pacific (Abbott et al. 2015, 2016). Benthic flux may also influence the here discussed core locations, but due to the stronger circulation in the Atlantic Ocean compared to the Pacific Ocean and the fact that benthic Nd fluxes would be expected to result in the most non-conservative behaviour at the sediment-water interface (in contrast to the findings of Blaser et al. (2019)), we expect it to be less relevant in the Atlantic. Additionally, whilst turbidites are prevalent in this region of the eastern North Atlantic and can result in the local overprinting of pore water $\varepsilon \mathrm{Nd}$ during early diagenesis, Blaser et al. (2019) found no evidence of vertical migration of $\mathrm{Nd}$ within sediments, nor any evidence of a turbidite-related benthic flux, indicating that this is only a concern for turbidite layers.
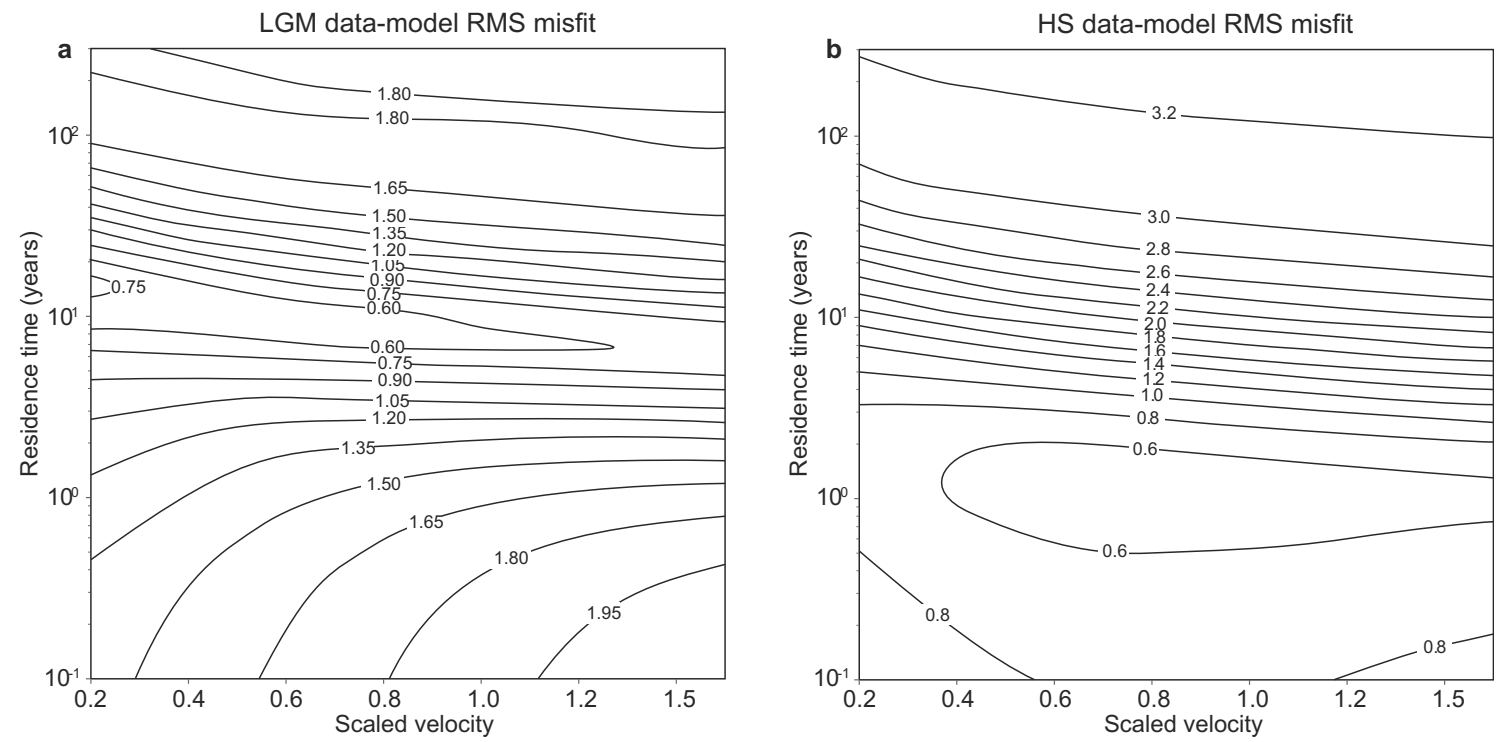

Fig. 9 Data-model RMS misfit $(\varepsilon N d)$ plotted as a function of residence time (scavenging intensity) and scaled water velocity, as in Fig. 8, for a LGM data and b HS data (Fig. 7). The BOFS $10 \mathrm{~K}$ site $(2777 \mathrm{~m})$ is excluded as this point is difficult to reconcile with all profiles 


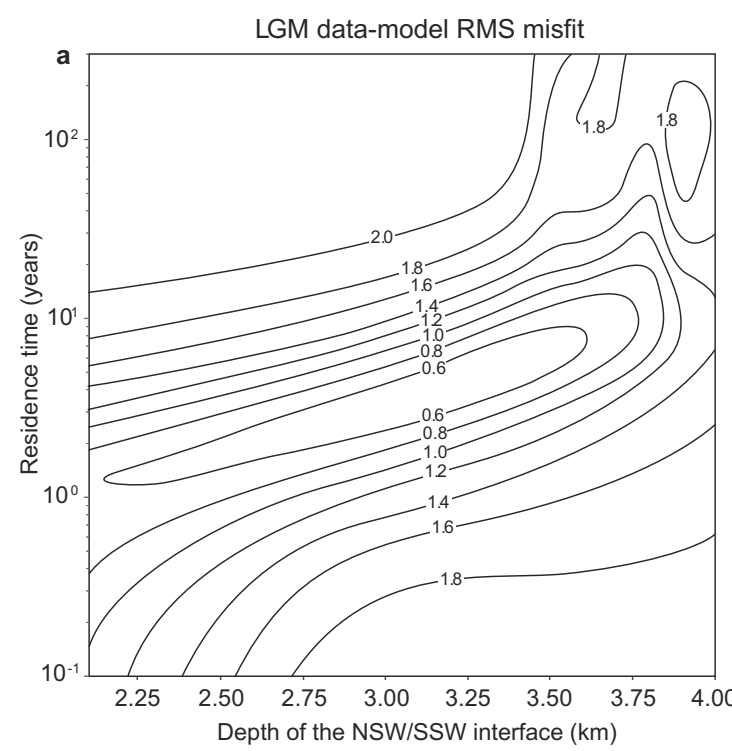

Fig. 10 Data-model RMS misfit $(\varepsilon N d)$ plotted as a function of residence time (scavenging intensity) and NSW-SSW interface depth, using the LGM-like and HS-like velocity profile scalings (justified due to the relative insensitivity to velocity, e.g. Fig. 9), for a LGM data and b HS data as

Nevertheless, the effects of benthic Nd fluxes on water column $\varepsilon N d$ have been tested to verify whether the very high scavenging rates implied by the above simulations are necessary. With a residence time of $\tau=300$ years (stronger scavenging intensities would overpower the effects of any benthic $\mathrm{Nd}$ flux) under the HS velocity profile, a $\varepsilon \mathrm{Nd}_{\text {pore water }}$ of -6.5 results in a $\varepsilon \mathrm{Nd}_{\mathrm{d}}$ profile that is within the range of the reconstructed HS profile of Blaser et al. (2019) (Fig. 11e). However, under the same parameters, switching to the LGM velocity profile results in poor model-data fit (Fig. 11f). Modifying the $\varepsilon \mathrm{Nd}_{\text {pore water }}$ for the LGM (Fig. 11g) still fails to reproduce the reconstructed $\varepsilon \mathrm{Nd}$ gradient. In any case, we cannot suggest any justification for significantly modifying pore water properties between the LGM and HSs, at least not in a way that results in good model-data fit. The above simulations also assume extreme values for diffusivity, $[\mathrm{Nd}]_{\text {pore fluid }}$ and piston velocity - under more realistic estimates, the effects of benthic Nd fluxes are significantly reduced.

Therefore, whilst our model results suggest that Nd fluxes can feasibly modify bottom water $\varepsilon \mathrm{Nd}_{\mathrm{d}}$, it cannot explain the differences between the Dreizack LGM and HS $\varepsilon \mathrm{Nd}$ profiles (Fig. 2), suggesting that it is not the main cause of this nonconservative behaviour.

\section{Reversible scavenging as a source of non-conservative $\varepsilon N d$ behaviour}

In the modern ocean, the residence time of $\mathrm{Nd}$ is on the order of several centuries (Tachikawa et al. 2003). That Nd appears to behave quasi-conservatively in the present (van de Flierdt et al. 2016; Tachikawa et al. 2017) is therefore consistent with

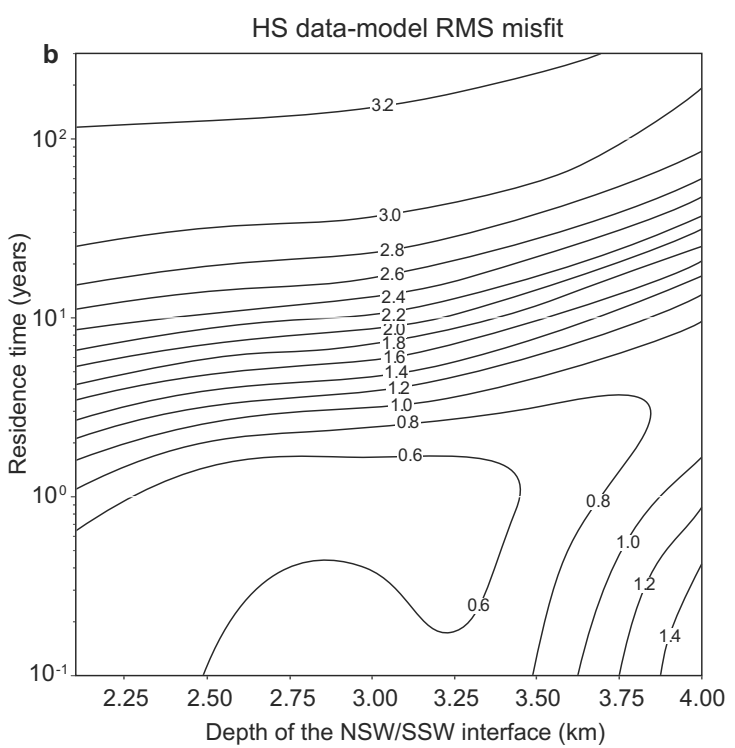

in Fig. 9. The NSW/SSW interface depth was modified by simply linearly shifting the default interface up or down, using the top/bottom water velocity to fill in the blanks. Note that this simple approach may generate unrealistic velocities in the shallowest/deepest waters

our model results (Fig. 7a). As discussed in "Scavenging rates", the scavenging rates used by the model, $K$ and $K$, can be considered as a function of the material adsorption and desorption rates for IRD components, and the concentration of these components in the water column. In particular, these reactions are a function of surface area rather than volume. One can therefore simplistically assume that:

$K=\sum A_{i} S_{i}$

$K^{-}=\sum D_{i} S_{i}$

where $A_{i}$ and $D_{i}$ are the specific adsorption and desorption rates of Nd with component $i$ per $\mathrm{m}^{2}\left(\mathrm{~m}^{-2} \mathrm{~s}^{-1}\right)$ and $S_{i}$ is the surface area of component $i$ per $\mathrm{m}^{3}$ of water $\left(\mathrm{m}^{-1}\right)$. For the sake of simplicity, the average geometry, volume and speciation of IRD particles is assumed to be temporally and spatially constant, which in turn results in a constant settling rate. Under these assumptions, $K$ and $K^{-}$are proportional to IRD accumulation rate.

The model prediction is that $K\left(=K^{-}\right)$should increase by a factor of approximately 10 between the LGM and Heinrich Stadials. Using the above assumptions, one would therefore expect a factor of 10 increases in IRD mass flux during Heinrich Stadials versus the LGM, and this is indeed within the range observed in sediment cores (Haapaniemi et al. 2010; McManus et al. 1998).

Despite this agreement, the problem remains that the model still predicts residence times for $\mathrm{Nd}$ in the glacial eastern North Atlantic significantly below the residence time of $\mathrm{Nd}$ in the global ocean. To test whether this is realistic, it would be useful to know reasonable values 
Fig. 11 Modelled steady-state $\varepsilon \mathrm{Nd}$ profiles, a, $\mathbf{b}$ for the LGM and HS cases with a hypothetical diagenetic $\varepsilon \mathrm{Nd}$ profile (dashed) added, assuming $1 \%$ particle dissolution in the sediment and a sediment:water column concentration factor of $10^{3} ; \mathbf{c}, \mathbf{d}$ for the LGM case with $\tau=$ 300 years and $\kappa_{D}=10^{-5}$ and $10^{-3} \mathrm{~m}^{2} \mathrm{~s}^{-1}$ respectively; e, f, g with benthic flux switched on with $\kappa_{D}=5 \times 10^{-4}$ with a piston velocity of $3 \times 10^{-7} \mathrm{~m} \mathrm{~s}^{-1}$ and $[\mathrm{Nd}]_{p f}=1000 \mathrm{pM}$ (q.v. Abbott et al. 2015)
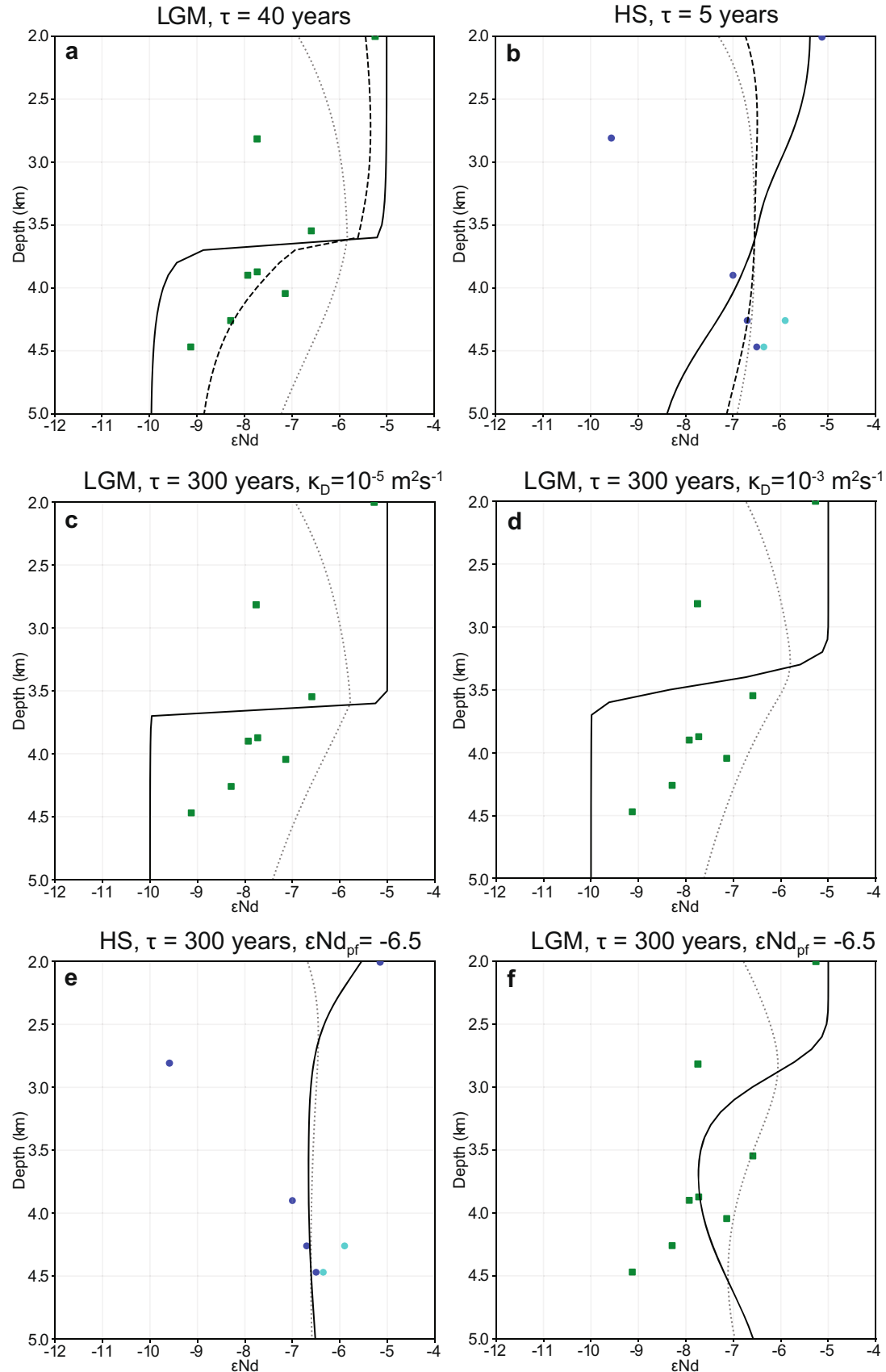

LGM, $\tau=300$ years, $\varepsilon \mathrm{Nd}_{\mathrm{pf}}=-10$
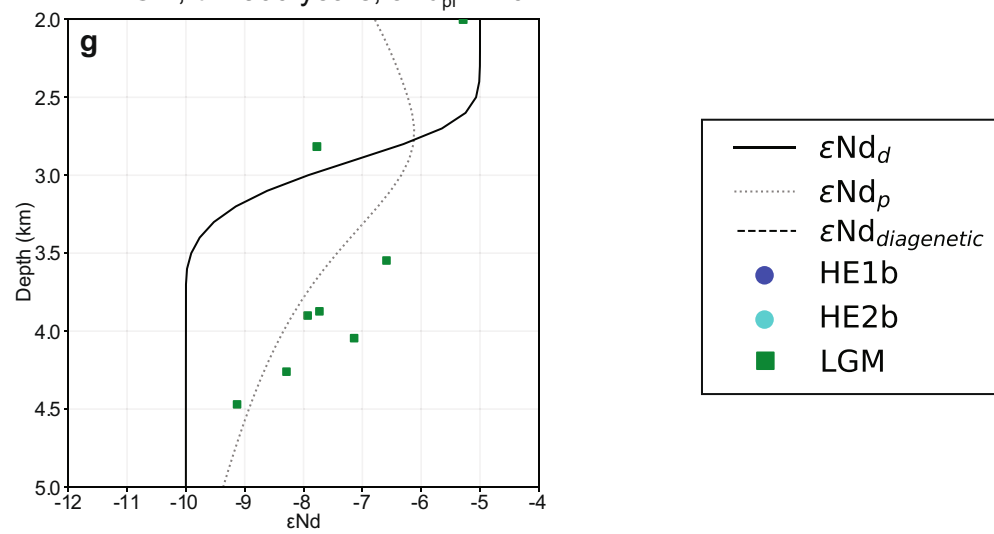
for $A_{i}$ and $D_{i}$ for specific IRD components (or even lithics in general) as described above, but to our knowledge these parameters do not yet exist. Obtaining these constraints is complicated by the fact that IRD entering the modern North Atlantic is highly heterogenous (Maslov et al. 2018) and lacks the detrital carbonate contribution from the Laurentide Ice Sheet (Broecker et al. 1992).

An additional complication is the significantly different $\varepsilon N d$ profiles that can be obtained if diagenetic contributions from adsorbed Nd are allowed (Fig. 11a, b), particularly with higher residence times when $\varepsilon \mathrm{Nd}_{\mathrm{d}}$ and $\varepsilon \mathrm{Nd}_{\mathrm{ads}}$ are significantly offset (e.g. Fig. 11a). In this case, matching reconstructed $\varepsilon N d$ profiles with the model becomes a curve fitting exercise. The purpose of Fig. 11 is therefore not to suggest that the modelled diagenetic system (1000-fold particle concentration in the sediment versus the water column and $1 \%$ dissolution) is realistic, but to demonstrate that the return of $\mathrm{Nd}$ from the adsorbed phase to diagenetic fluids could significantly alter the archived $\varepsilon \mathrm{Nd}_{\mathrm{d}}$ signal.

\section{Modern analogues}

Recent studies from the Panama Basin (Grasse et al. 2017) and Bay of Bengal (Yu et al. 2017) find evidence of variability in $\varepsilon \mathrm{Nd}$ of deep waters on annual timescales that is not associated with changes in hydrography. If this is indeed the case, whilst these two cases are clearly in a very different setting to the glacial IRD belt, this provides two modern examples of significantly non-conservative behaviour in the $\varepsilon \mathrm{Nd}$ of deep waters in the modern ocean and the suggestion of short (annual to decadal) residence times in the glacial and deglaciating eastern North Atlantic becomes more believable. Both settings of the studies, the Panama Basin and Bay of Bengal, are characterised by high particle fluxes (biogenic and lithogenic). However, the mineralogy of these particles differs from that of typical Ruddiman-belt IRD and in both of these cases; the authors argue that particles are either acting as $\mathrm{Nd}$ sources or sinks rather than implicating reversible scavenging.

\section{Conclusion}

Bottom water $\varepsilon$ Nd profiles for the LGM and Heinrich Stadials 1 and 2 in the eastern North Atlantic, obtained from sediment cores from the Dreizack Seamount (Roberts and Piotrowski 2015; Blaser et al. 2019) show patterns that are difficult to reconcile with assumptions of conservative $\varepsilon \mathrm{Nd}$ behaviour. Using a simple water column box model, we have demonstrated that reversible scavenging processes are capable of producing simulated $\varepsilon \mathrm{Nd}$ profiles that fit well with geochemical reconstructions for the LGM and Heinrich Stadials (Fig. 7), necessitating a (localised) residence time on the order of 110 years within the North Atlantic IRD belt, significantly lower than the centennial-scale residence times for the ocean as a whole (Tachikawa et al. 2003). Furthermore, the predicted relative increase in scavenging intensity between the LGM and Heinrich Stadials is in agreement with the relative increase in IRD intensity. Whilst it is unclear how compatible this theory is with a significantly shoaled glacial NSW/SSW interface in the eastern North Atlantic, mechanisms that do not include reversible scavenging still fail to explain the observed $\varepsilon N d$ gradients. Whilst we cannot fully rule out alternative explanations such as conservative behaviour or benthic $\mathrm{Nd}$ fluxes, both explanations would require physical or chemical changes in the glacial and deglaciating eastern North Atlantic that are difficult to justify. We emphasise that this is an idealised proof-of-concept study - the idealised model used in this study clearly does not incorporate the full complexity of the biogeochemical cycling of Nd in the north Atlantic and relies on many unconstrained parameters. This model nevertheless enables the broad quantification of the scavenging rates required to reproduce observations, and these scavenging rates may be physically reasonable. We therefore argue that the suggestion that IRD could cause non-conservative behaviour in $\varepsilon \mathrm{Nd}$ is worth taking seriously.

Given the importance of reconstructing past ocean circulation for understanding the role of the oceans in abrupt climate variability and the potential applications of $\varepsilon \mathrm{Nd}$ as a palaeotracer, it is essential to have a good understanding of the geochemical cycling of $\mathrm{Nd}$ in the oceans and whether assumptions of conservative behaviour, as appears to be the case in most of the modern ocean (albeit with the exceptions detailed in "Modern analogues") holds true for the past as well. If it is correct that processes such as IRD deposition (and potentially others such as productivity, dust deposition and sediment plumes from rivers) can cause significant localised non-conservative behaviour in palaeotracers, then this has serious implications for the use of these tracers in palaeoceanographical reconstructions, particularly where the modification of end-member properties is possible (as is the case in the North Atlantic). We therefore emphasise the importance of multi-proxy approaches to palaeoceanography, as well as the careful consideration of the processes involved in palaeotracer systems rather than simply considering them as simple two-component systems with fixed end-members.

Key uncertainties remain regarding the use of $\mathrm{Nd}$ as a palaeotracer, principally a lack of fundamental chemical constraints on adsorption-desorption rates of Nd with IRD components and a poor understanding of the effects of diagenesis on the $\varepsilon \mathrm{Nd}$ records in different sedimentary phases. We nevertheless conclude that the assumption of conservative $\varepsilon \mathrm{Nd}$ behaviour in this oceanographical setting is sufficiently uncertain that it warrants further investigation. 
Acknowledgements Hartmut Schultz, University of Tübingen, is thanked for providing sample material. We further thank Frerk Pöppelmeier, Heidelberg University, for analytical support, and the two anonymous reviewers for their comments which improved this manuscript.

We thank the Laidlaw Scholars Undergraduate Research \& Leadership Programme at the University of Oxford for enabling this project.

Funding information Financial support for this research was provided by the Emmy-Noether Programme of the Deutsche Forschungsgemeinschaft through grant LI1815/4.

Open Access This article is licensed under a Creative Commons Attribution 4.0 International License, which permits use, sharing, adaptation, distribution and reproduction in any medium or format, as long as you give appropriate credit to the original author(s) and the source, provide a link to the Creative Commons licence, and indicate if changes were made. The images or other third party material in this article are included in the article's Creative Commons licence, unless indicated otherwise in a credit line to the material. If material is not included in the article's Creative Commons licence and your intended use is not permitted by statutory regulation or exceeds the permitted use, you will need to obtain permission directly from the copyright holder. To view a copy of this licence, visit http://creativecommons.org/licenses/by/4.0/.

\section{References}

Abbott AN, Haley BA, McManus J (2015) Bottoms up: sedimentary control of the deep North Pacific Ocean's $\varepsilon N d$ signature. Geology 43:1035-1038. https://doi.org/10.1130/G37114.1

Abbott AN, Haley BA, McManus J (2016) The impact of sedimentary coatings on the diagenetic Nd flux. Earth Planet Sci Lett 449:217227. https://doi.org/10.1016/j.epsl.2016.06.001

Arsouze T, Dutay JC, Lacan F, Jeandel C (2007) Modeling the neodymium isotopic composition with a global ocean circulation model. Chem Geol 239:165-177. https://doi.org/10.1016/j.chemgeo.2006.12.006

Arsouze T, Dutay JC, Lacan F, Jeandel C (2009) Reconstructing the Nd oceanic cycle using a coupled dynamical - biogeochemical model. Biogeosciences 6:2829-2846

Bacon MP, Anderson RF (1982) Distribution of thorium isotopes between dissolved and particulate forms in the deep sea. J Geophys Res 87(C3):2045-2056. https://doi.org/10.1029/jc087ic03p02045

Blaser P, Pöppelmeier F, Schulz H, Gutjahr M, Frank M, Lippold J (2019) The resilience and sensitivity of Northeast Atlantic deep water eNd to overprinting by detrital fluxes over the past 30,000 years. Geochi Cosmochim Acta 245:79-97. https://doi.org/10.1016/j.gca.2018.10.018

Böhm E, Lippold J, Gutjahr M, Frank M, Blaser P, Antz B, Fohlmeister J, Frank N, Andersen MB, Deininger M (2015) Strong and deep Atlantic meridional overturning circulation during the last glacial cycle. Nature 517:73-76. https://doi.org/10.1038/nature14059

Bond G, Hartmut H, Broecker W, Labeyrie LD, McManus J, Huon JT et al (2012) Lithic grains in MIS4-2 of DSDP Site 94-609, large fraction. PANGAEA. https://doi.org/10.1594/PANGAEA.834690

Bradtmiller LI, McManus JF, Robinson LF (2014) 231Pa/230Th evidence for a weakened but persistent Atlantic meridional overturning circulation during Heinrich Stadial 1. Nat Commun 5:5817. https:// doi.org/10.1038/ncomms6817

Broecker W, Bond G, Klas M, Clark E, McManus J (1992) Origin of the northern Atlantic's Heinrich events. Clim Dyn 6:265-273. https:// doi.org/10.1007/BF00193540
Buckley MW, Marshall J (2015) Observations, inferences, andmechanisms of the Atlantic meridional overturning circulation: a review. Rev Geophys 54:5-63. https://doi.org/10.1002/ 2015RG000493.Received

Chen AT, Robinson LF, Burke A, Southon J, Spooner P, Morris PJ et al (2015) Synchronous sub-millennial scale abrupt events in the ocean and atmosphere during the last deglaciation. Science 1(80):15371542. https://doi.org/10.1126/science.aac6159

Cheng W, Chiang JCH, Zhang D (2013) Atlantic meridional overturning circulation (AMOC) in CMIP5 models: RCP and historical simulations. J Clim 26:7187-7197. https://doi.org/10.1175/JCLI-D-1200496.1

Curry WB, Oppo DW (2005) Glacial water mass geometry and the distribution of $813 \mathrm{C}$ of $\Sigma \mathrm{CO} 2$ in the western Atlantic Ocean. Paleoceanography 20:1-12. https://doi.org/10.1029/2004PA001021

Ericson DB (1959) Coiling direction of globigerina pachyderma as a climatic index. Science 130(3369):219-220. https://doi.org/10. 1126/science.130.3369.219

Freeman E, Skinner LC, Waelbroeck C, Hodell D (2016) Radiocarbon evidence for enhanced respired carbon storage in the Atlantic at the Last Glacial Maximum. Nat Commun 7:1-8. https://doi.org/10. 1038/ncomms 11998

Ganachaud A, Wunsch C (2000) Improved estimates of global ocean circulation, heat transportandmixing from hydrographic data. Nature 408:453-457. https://doi.org/10.1007/s00408-017-9981-9

Gebbie G (2014) How much did glacial North Atlantic water shoal? Paleoceanography 29:190-209. https://doi.org/10.1002/2013PA002557

Gherardi JM, Labeyrie L, McManus JF, Francois R, Skinner LC, Cortijo E (2005) Evidence from the northeastern Atlantic basin for variability in the rate of the meridional overturning circulation through the last deglaciation. Earth Planet Sci Lett 240:710-723. https://doi.org/ 10.1016/j.epsl.2005.09.061

Gherardi JM, Labeyrie L, Nave S, Francois R, McManus JF, Cortijo E (2009) Glacial-interglacial circulation changes inferred from $231 \mathrm{~Pa} / 230 \mathrm{Th}$ sedimentary record in the North Atlantic region. Paleoceanography 24: PA2204. https://doi.org/10.1029/2008PA001696

Grasse P, Bosse L, Hathorne EC, Böning P, Pahnke K, Frank M (2017) Short-term variability of dissolved rare earth elements and neodymium isotopes in the entire water column of the Panama Basin. Earth Planet Sci Lett 475:242-253. https://doi.org/10.1016/j.epsl.2017.07.022

Haapaniemi AI, Scourse JD, Peck VL, Kennedy H, Kennedy P, Hemming SR et al (2010) Source, timing, frequency and flux of ice-rafted detritus to the Northeast Atlantic margin, 30-12 ka: testing the Heinrich precursor hypothesis. Boreas 39:576-591. https://doi. org/10.1111/j.1502-3885.2010.00141.x

Hayes CT, Anderson RF, Cheng H, Conway TM, Edwards RL, Fleisher MQ et al (2018) Replacement times of a spectrum of elements in the North Atlantic based on thorium supply. Glob Biogeochem Cycles. https://doi.org/10.1029/2017GB005839

Heinrich H (1988) Origin and consequences of cyclic ice rafting in the Northeast Atlantic Ocean during the past 130,000 years. Quat Res 29:142-152. https://doi.org/10.1016/0033-5894(88)90057-9

Hodell DA, Nicholl JA, Bontognali TRR, Danino S, Dorador J, Dowdeswell JA et al (2017) Anatomy of Heinrich layer 1 and its role in the last deglaciation. Paleoceanography 32:284-303. https:// doi.org/10.1002/2016PA003028

Howe JNW, Piotrowski AM, Noble TL, Mulitza S, Chiessi CM, Bayon G (2016a) North Atlantic deep water production during the Last Glacial Maximum. Nat Commun 7:1-8. https://doi.org/10.1038/ ncomms 11765

Howe JNW, Piotrowski AM, Rennie VCF (2016b) Abyssal origin for the early Holocene pulse of unradiogenic neodymium isotopes in 
Atlantic seawater. Geology 44:831-834. https://doi.org/10.1130/ G38155.1

Jackson LC, Kahana R, Graham T, Ringer MA, Woollings T, Mecking JV et al (2015) Global and European climate impacts of a slowdown of the AMOC in a high resolution GCM. Clim Dyn 45:3299-3316. https://doi.org/10.1007/s00382-015-2540-2

Jones KM, Khatiwala SP, Goldstein SL, Hemming SR, van de Flierdt T (2008) Modeling the distribution of Nd isotopes in the oceans using an ocean general circulation model. Earth Planet Sci Lett 272:610 619. https://doi.org/10.1016/j.epsl.2008.05.027

Kohfeld KE, Fairbanks RG, Smith SL, Walsh ID (1996) Neogloboquadrina pachyderma (sinistral coiling) as paleoceanographic tracers in polar oceans - evidence from northeast water polynya plankton tows, sediment traps, and surface sediments. Paleoceanography 11:679-699

Lippold J, Luo Y, Francois R, Allen SE, Gherardi J, Pichat S et al (2012) Strength and geometry of the glacial Atlantic meridional overturning circulation. Nat Geosci 5:813-816. https://doi.org/10.1038/ ngeo 1608

Lippold J, Gutjahr M, Blaser P, Christner E, de Carvalho Ferreira ML, Mulitza S et al (2016) Deep water provenance and dynamics of the (de)glacial Atlantic meridional overturning circulation. Earth Planet Sci Lett 445:68-78. https://doi.org/10.1016/j.eps1.2016.04.013

Luo Y, Francois R, Allen S (2010) Sediment 231Pa/230Th as a recorder of the rate of the Atlantic meridional overturning circulation: insights from a 2-D model. Ocean Sci 6:381-400. https://doi.org/10. 5194/os-6-381-2010

Lynch-Stieglitz J, Schmidt MW, Gene Henry L, Curry WB, Skinner LC, Mulitza S, Zhang R, Chang P (2014) Muted change in Atlantic overturning circulation over some glacial-aged Heinrich events. Nat Geosci 7:144-150. https://doi.org/10.1038/ngeo2045

Marchitto TM, Broecker WS (2006) Deep water mass geometry in the glacial Atlantic Ocean: a review of constraints from the paleonutrient proxy $\mathrm{Cd} / \mathrm{Ca}$. Geochem Geophys Geosyst 7. https:// doi.org/10.1029/2006GC001323

Marshall J, Scott JR, Armour KC, Campin JM, Kelley M, Romanou A (2015) The ocean's role in the transient response of climate to abrupt greenhouse gas forcing. Clim Dyn 44:2287-2299. https://doi.org/ 10.1007/s00382-014-2308-0

Maslov AV, Shevchenko VP, Kuznetsov AB, Stein R (2018) Geochemical and $\mathrm{Sr}-\mathrm{Nd}-\mathrm{Pb}$-isotope characteristics of ice-rafted sediments of the Arctic Ocean. Geochem Int 56:751-765. https:// doi.org/10.1134/S0016702918080050

McManus JF, Anderson RF, Broecker WS, Fleisher MQ, Higgins SM (1998) Radiometrically determined sedimentary fluxes in the subpolar North Atlantic during the last 140,000 years. Earth Planet Sci Lett 155:29-43. https://doi.org/10.1016/S0012-821X(97)00201-X

McManus JF, Francois R, Gherardl JM, Kelgwin L, Drown-Leger S (2004) Collapse and rapid resumption of Atlantic meridional circulation linked to deglacial climate changes. Nature 428:834-837. https://doi.org/10.1038/nature02494

Obrochta SP, Miyahara H, Yokoyama Y, Crowley TJ (2012) A reexamination of evidence for the North Atlantic " 1500-year cycle" at site 609. Quat Sci Rev. https://doi.org/10.1016/j.quascirev.2012. 08.008

Oppo DW, Lehman SJ (1993) Mid-depth circulation of the subpolar North Atlantic during the Last Glacial Maximum. Science 259(80):1148-1152. https://doi.org/10.1126/science.259.5098.1148

Piotrowski AM, Galy A, Nicholl JAL, Roberts N, Wilson DJ, Clegg JA et al (2012) Reconstructing deglacial North and South Atlantic deep water sourcing using foraminiferal Nd isotopes. Earth Planet Sci Lett 357-358:289-297. https://doi.org/10.1016/j.epsl.2012.09.036
Polzin KL, Toole JM, Ledwell JR, Schmitt RW (1997) Ocean spatial variability of turbulent mixing in the Abyssal Ocean. Science 276(80):93-96. https://doi.org/10.1126/science.276.5309.93

Pöppelmeier F, Gutjahr M, Blaser P, Keigwin LD, Lippold J (2018) Origin of abyssal NW Atlantic water masses since the Last Glacial Maximum. Paleoceanogr Paleoclimatol 33:530-543. https://doi.org/ 10.1029/2017PA003290

Praetorius SK, McManus JF, Oppo DW, Curry WB (2008) Episodic reductions in bottom-water currents since the last ice age. Nat Geosci 1:449-452. https://doi.org/10.1038/ngeo227

Rempfer J, Stocker TF, Joos F, Dutay J-C (2012) On the relationship between $\mathrm{Nd}$ isotopic composition and ocean overturning circulation in idealized freshwater discharge events. Paleoceanography 27(3): 1-24. https://doi.org/10.1029/2012PA002312

Rickaby REM, Elderfield H (2005) Evidence from the high-latitude North Atlantic for variations in Antarctic Intermediate water flow during the last deglaciation. Geochem Geophys Geosyst 6. https:// doi.org/10.1029/2004GC000858

Roberts NL, Piotrowski AM (2015) Radiogenic Nd isotope labeling of the northern NE Atlantic during MIS 2. Earth Planet Sci Lett 423: 125-133. https://doi.org/10.1016/j.epsl.2015.05.011

Stouffer R, Yin J, Gregory J, Dixon K, Spelman M (2006) Investigating the causes of the response of the thermohaline circulation to past and. J Clim 19:1365-1387. https://doi.org/10.1002/9781119115397.ch25

Tachikawa K, Jeandel C, Dupré B (1997) Distribution of rare earth elements and neodymium isotopes in settling particulate material of the tropical Atlantic Ocean (EUMELI site). Deep Res Part I Oceanogr Res Pap 44: 1769-1792. https://doi.org/10.1016/S0967-0637(97)00057-5

Tachikawa K, Athias V, Jeandel C (2003) Neodymium budget in the modern ocean and paleo-oceanographic implications. J Geophys Res 108. https://doi.org/10.1029/1999JC000285

Tachikawa K, Arsouze T, Bayon G, Bory A, Colin C, Dutay JC et al (2017) The large-scale evolution of neodymium isotopic composition in the global modern and Holocene ocean revealed from seawater and archive data. Chem Geol. https://doi.org/10.1016/j. chemgeo.2017.03.018

Thornalley DJR, Barker S, Broecker WS, Elderfield H, McCave IN (2011) The deglacial evolution of North Atlantic deep convection. Science 331(80):202-205. https://doi.org/10.1126/science.1196812

Toole JM, Schmitt RW, Polzin KL (1997) Near-boundary mixing above the flanks of a midlatitude seamount. J Geophys Res 102:947-959

van Aken HM (2000) The hydrography of the mid-latitude Northeast Atlantic Ocean I: the deep water masses. Deep-Sea Res I: Oceanogr Res Pap 47(5):757-788. https://doi.org/10.1016/S09670637(99)00092-8

van de Flierdt T, Pahnke K, Amakawa H, Andersson P, Basak C, Coles B et al (2012) GEOTRACES intercalibration of neodymium isotopes and rare earth element concentrations in seawater and suspended particles. Part 1: reproducibility of results for the international intercomparison. Limnol Oceanogr Methods 10:234-251. https://doi. org/10.4319/lom.2012.10.234

van de Flierdt T, Griffiths AM, Lambelet M, Little SH, Stichel T, Wilson DJ (2016) Neodymium in the oceans: a global database, a regional comparison and implications for palaeoceanographic research. Philos Trans R Soc A Math Phys Eng Sci 374. https://doi.org/10. 1098/rsta.2015.0293

Wei R, Abouchami W, Zahn R, Masque P (2016) Deep circulation changes in the South Atlantic since the Last Glacial Maximum from Nd isotope and multi-proxy records. Earth Planet Sci Lett 434:18-29. https://doi.org/10.1016/j.epsl.2015.11.001

Wilson DJ, Crocket KC, Van De Flierdt T, Robinson LF, Adkins JF (2014) Dynamic intermediate ocean circulation in the North 
Atlantic during Heinrich Stadial 1: a radiocarbon and neodymium isotope perspective. Paleoceanography 29:1072-1093. https://doi. org/10.1002/2014PA002674

Yu E-F, Francois R, Bacon MP (1996) Similar rates of modern and lastglacial ocean thermohaline circulation inferred from radiochemical data. Nature 379:689-694. https://doi.org/10.1038/379689a0

Yu J, Elderfield H, Piotrowski AM (2008) Seawater carbonate ion- $\delta 13 \mathrm{C}$ systematics and application to glacial-interglacial North Atlantic ocean circulation. Earth Planet Sci Lett 271:209-220. https://doi. org/10.1016/j.epsl.2008.04.010
Yu Z, Colin C, Meynadier L, Douville E, Dapoigny A, Reverdin G et al (2017) Seasonal variations in dissolved neodymium isotope composition in the Bay of Bengal. Earth Planet Sci Lett 479:310-321. https://doi.org/10.1016/j.epsl.2017.09.022

Zhang R, Delworth TL (2005) Simulated tropical response to a substantial weakening of the Atlantic. J Clim 128:1853-1860. https://doi. org/10.1175/JCLI3460.1

Publisher's note Springer Nature remains neutral with regard to jurisdictional claims in published maps and institutional affiliations. 